\title{
Mechanism and Prevention of Rockburst in Steeply Inclined and Extremely Thick Coal Seams for Fully Mechanized Top-Coal Caving Mining and Under Gob Filling Conditions
}

\author{
Shengquan He ${ }^{1,2}$, Dazhao Song ${ }^{1,2, *}$, Zhenlei Li ${ }^{1,2}$, Xueqiu He ${ }^{1,2,3}$, Jianqiang Chen ${ }^{4}$, \\ Taoping Zhong ${ }^{1,2}$ and Quan Lou ${ }^{5}$ \\ 1 School of Civil and Resources Engineering, University of Science \& Technology Beijing, Beijing 100083, \\ China; b20170061@xs.ustb.edu.cn (S.H.); lizhenlei@ustb.edu.cn (Z.L.); hexq@ustb.edu.cn (X.H.); \\ g20188141@xs.ustb.edu.cn (T.Z.) \\ 2 Key Laboratory of Ministry of Education for Efficient Mining and Safety of Metal Mine, University of Science \\ \& Technology Beijing, Beijing 100083, China \\ 3 Zhong-an Academy of Safety Engineering, Beijing 100083, China \\ 4 Shenhua Xinjiang Energy Company Limited, Urumqi 830027, China; chenjq8@126.com \\ 5 School of Municipal and Environmental Engineering, Henan University of Urban Construction, \\ Pingdingshan 467036, China; louquan0501@163.com \\ * Correspondence: songdz@ustb.edu.cn; Tel.: +86-185-1513-9977
}

Received: 16 January 2020; Accepted: 10 March 2020; Published: 15 March 2020

check for updates

\begin{abstract}
The steeply inclined and extremely thick coal seams (SIETCS) under the condition of gob filling frequently suffer from the occurrence of rockbursts. Figuring out the mechanisms of rockbursts under this condition for taking targeted measures to mitigate rockburst hazards in SIETCS is of great significance. Using the typical SIETCS with an average dip angle of $87^{\circ}$ at Wudong Coal Mine (WCM) as a case study, a mechanical model and elastic deformation energy (EDE) function of a "steeply inclined suspended roof structure" was developed, and the influence factors were analyzed by theoretical analysis. Simultaneously, the rockburst risk assessment was carried out based on the theory of a rockburst start-up. The pressure relief measures are optimized by comparing the pressure relief effects of three kinds of destress blasting schemes. The results indicate that the damage characteristics of rockburst are mainly floor heave, the sidewall's inward deformation and roof subsidence. The damage degree of headentry on the roof side is more severe than that of tailentry, and the resultant impacts showed the directionality from the roof side to the coal side. The steeply inclined and suspended roof breakage is one of the main causes for the occurrence of rockbursts. The EDE of the roof increases with an increasing dip angle of the coal seam from $0^{\circ}$ to $72.6^{\circ}$ and then decreases as the dip angle increases. Furthermore, that increase is accompanied by the decrease of the lateral pressure coefficient and the supporting force coefficient. The EDE stored in the roof is sufficient to cause roof breakage and induce rockburst after the complete roof exceeds a certain length. The mechanism of rockburst in SIETCS for fully mechanized top-coal caving mining under gob filling conditions was proposed, i.e., "high compressive stress concentration plus breakage of the suspended roof-induced stress" rockburst, and this is further verified by ground destruction, microseismic (MS) monitoring and numerical modeling. The results also indicate that alternate deep and shallow hole-blasting modes are more suitable for pressure relief in SIETCS.
\end{abstract}

Keywords: rockburst; steeply inclined and extremely thick coal seam; mechanical model; elastic deformation energy; roof breakage; destress blasting 


\section{Introduction}

Coal accounts for $60-70 \%$ of China's disposable energy consumption structure. The economy in Eastern China is developing rapidly, and the demand for coal is large, resulting in a gradual depletion of coal resources [1]. Currently, the mining depth of most coal mines in China is over $1000 \mathrm{~m}$. Due to the high geostress and complex geological structures, rockbursts occur frequently in deep coal seams, which are difficult to control and cause serious losses [2-7]. About 180 coal mines in China experienced rockburst hazards until 2017 [8]. Western China is gradually shifting from a strategic resource reserve area to a production area, becoming the main mining area in recent years. However, the northwest mainly consists of inclined and steeply inclined coal seams, accounting for about $60 \%$ of the total coal. The steeply inclined coal seam is formed by a large-scale bending and torsion under the stress dominated by geological structures, which has a large dip angle and is prone to occurring rockburst.

Currently, many studies on the mechanism of rockburst have been conducted by researchers domestically and abroad [9-16]. The researches on the mechanisms of rockburst mainly start from three aspects: mechanical properties of coal and rock, static stress and dynamic load disturbance [14]. A rockburst may occur in a coal mine that with rockburst proneness when the total stress (the superposition value of the static stress in the coal and the dynamic stress induced by tremors) reaches the critical stress required for rockburst formation [13,17-19]. The mechanical parameters of coal and rock mass are mainly obtained by a uniaxial compression test $[20,21]$. The static stress in coal and rock mass is mainly studied by theoretical derivation, numerical simulation and in situ stress test [22-24]. In situ stress test is the main means for stress monitoring, but the significant engineering demands for stress monitoring are causing high costs, and the monitoring range is limited [19]. Li et al. [13] revealed the mechanism of rockburst induced within fault pillars through theoretical derivation. Zhu et al. [8] revealed the stress distribution of deep island longwall panels and overlying strata by theoretical analysis and numerical simulation. Jiang et al. [25] and Wang et al. [20,26] researched the stress in an island panel subjected to periodic weighting by the Fast Lagrangian Analysis of Continua (FLAC) method and obtained that there is a higher rockburst risk at the location of the peak abutment stress. Marcak [27] reported that in many underground mines in Poland, the intensive stress of the curved roof is a dangerous cause of rockburst. Lai et al. [28] revealed that the stress concentration caused by the bending of the rock pillar between inclined coal seams was the main reason for the frequent rockbursts.

For dynamic disturbance, Bräuner [29] stated that the majority of the documented rockburst events are mainly roof rockburst, floor rockburst and sidewall (rib) rockburst, which mainly occurred in periods of strong dynamic disturbance, such as hard roof rupture, roadways advancements or when the working face is being mined [17,18,30,31]. Wang et al. [32] observed that dynamic disturbance contributed to a large proportion of rockbursts. Guo et al. [14] obtained that the high mining-induced stress is an important factor to induce rockburst by analyzing the six rockbursts that occurred in Jingxi Coalfield, and three types of rockburst mechanisms were proposed. The overhanging roof over the gob can store considerable elastic deformation energy (EDE) in the roof under the action of surrounding rock stress, which results in the roof periodic breakage and large dynamic disturbance [33]. A hard roof has a great influence on coal seam damage, because a high dynamic load is imposed on the coal when it breaks [34,35]. Zhu et al. [8] found that the rockburst occurred in deep island panels is mainly induced by the overall instability of the coal and rock around the working face. Chen et al. [36] reported that during hard roof breakage or slip instability, the rockburst will be induced easily under the influence of instantaneously releasing a large amount of elastic energy. Huang et al. [33] obtained that the rockburst may occur when the EDE stored in the roof reaches the maximum limit and is instantaneously released. Lai et al. [37] indicated that the inclined length of the roof beam has an impact on the roof deformation. The rockburst will occur when the superimposed dynamic stress caused by the inclined roof breaking and the high static stress exceeds the critical stress [38]. Therefore, it is significant to mitigate rockbursts by studying the stress and energy distributions on the hard-suspended roof.

However, the abovementioned studies mainly focused on horizontal and gently inclined coal seams in which the gob backfilling is not used and the roof is completely suspended, and only little 
research has been achieved for steeply inclined coal seams. Few systematic studies have been conducted to study the mechanism of rockburst in steeply inclined and extremely thick coal seams (SIETCS) under the conditions of gob filling when supporting the force of the backfilling material acts on the suspended roof. Due to the special structure of SIETCS, the large mining height and top coal caving mining method is easily causing the gob backfilling to sink instantaneously, thus leading the suspended roof to deform and show instability when it loses support. Moreover, the mining period of SIETCS is short; relevant studies of these kinds of coal seams are still limited, and the damage law, as well as the mechanism of rockburst, are not clear either. He et al. [39] obtained that the evolution laws of microseismic (MS) precursor information prior to rockburst is different between SIETCS and gently inclined coal seams. The practice shows that the rockbursts still occur if the previous rockburst-controlling methods in gently inclined coal seams are used in SIETCS. Therefore, studying the mechanism of rockburst and prevention methods in SIETCS for fully mechanized top-coal caving mining and under gob filling conditions is needed to ensure safe mining.

This paper first uses a typical SIETCS of Wudong Coal Mine (WCM), China as an example and summarizes the main rockburst damage characteristics by analyzing the typical rockbursts of SIETCS. Following this, a mechanical model of the "steeply inclined suspended roof structure" is established. The distribution of EDE on the roof and the main influencing factors are studied by theoretical analysis. The risk of roof rupture-induced rockbursts is then assessed according to the start-up energy criterion of the rockburst to reveal the rockburst mechanism. Furthermore, comprehensive surface damage measurements, MS monitoring and $\mathrm{FLAC}^{3 \mathrm{D}}$ simulation are used to verify the rockburst mechanism of the B3 +6 coal seam at +450 horizontal. Finally, the rockburst prevention and control measures of SIETCS are optimized in an attempt to provide guidelines for the effective prevention and control of rockburst in SIETCS.

\section{Rockburst in a SIETCS}

\subsection{Basic Conditions of the Coal Seam}

The selected coal seam is in WCM, China. WCM belongs to the Urumqi coalfield, which is located in the Northern foot of the Tianshan Mountains. The early tectonic movements and the strong uplift of the Tianshan Mountains, especially the Bogda Peak, have strongly squeezed the strata in the area. The research area of WCM is located in the South wing of the Badaowan syncline in Urumqi. The coal-bearing stratum is the Xishanyao Formation, which belongs to a monoclinic structure inclined southward. There is no fault or magma intrusion in the southern mining area of WCM. The overall section view of the coal seams distribution in WCM is shown in Figure 1, showing a syncline structure. Both the No. B3 +6 and B1 +2 coal seams of the WCM can be classified as SIETCS with dip angles of $87^{\circ}$; the full-mechanized top-coal caving mining method is being adopted, the ratio of mining to caving height is $1: 7$ and the horizontal section height is $25 \mathrm{~m}$. The mining level of the researched coal seam No. B3 +6 is located at the +450 horizontal, with the strike and sloping length of $2500 \mathrm{~m}$ and $48.9 \mathrm{~m}$, respectively. The maximum horizontal principal stress is about 1.74-1.90 times of the vertical stress, showing an intensive horizontal tectonic stress field characteristic. The gob above the +450 horizontal is filled with loess. A section view of the coal seams is shown in Figure 2, and the coal seams and rock types are shown in Figure 3. 


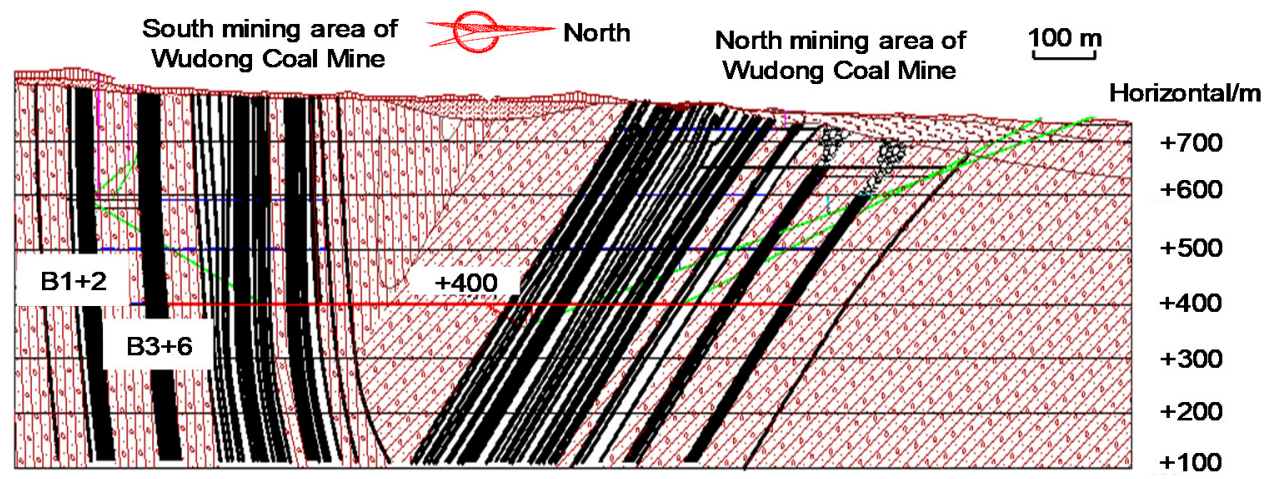

Figure 1. Section view of the coal seams distribution in the North and South area of the Wudong Coal Mine.

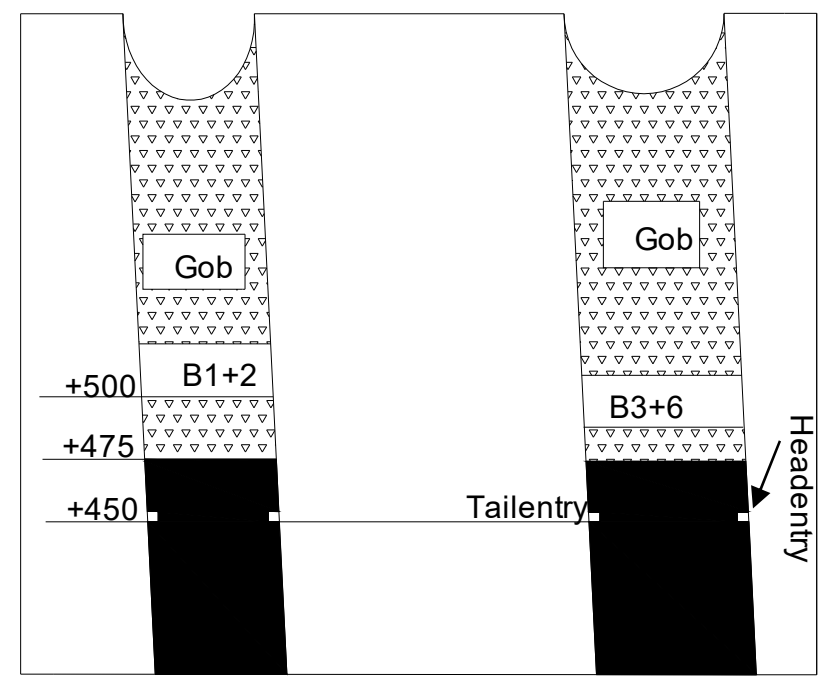

Figure 2. The section view of the coal seam (modified according to He et al. [39]. (Reproduced from [39], Elsevier: 2019.).

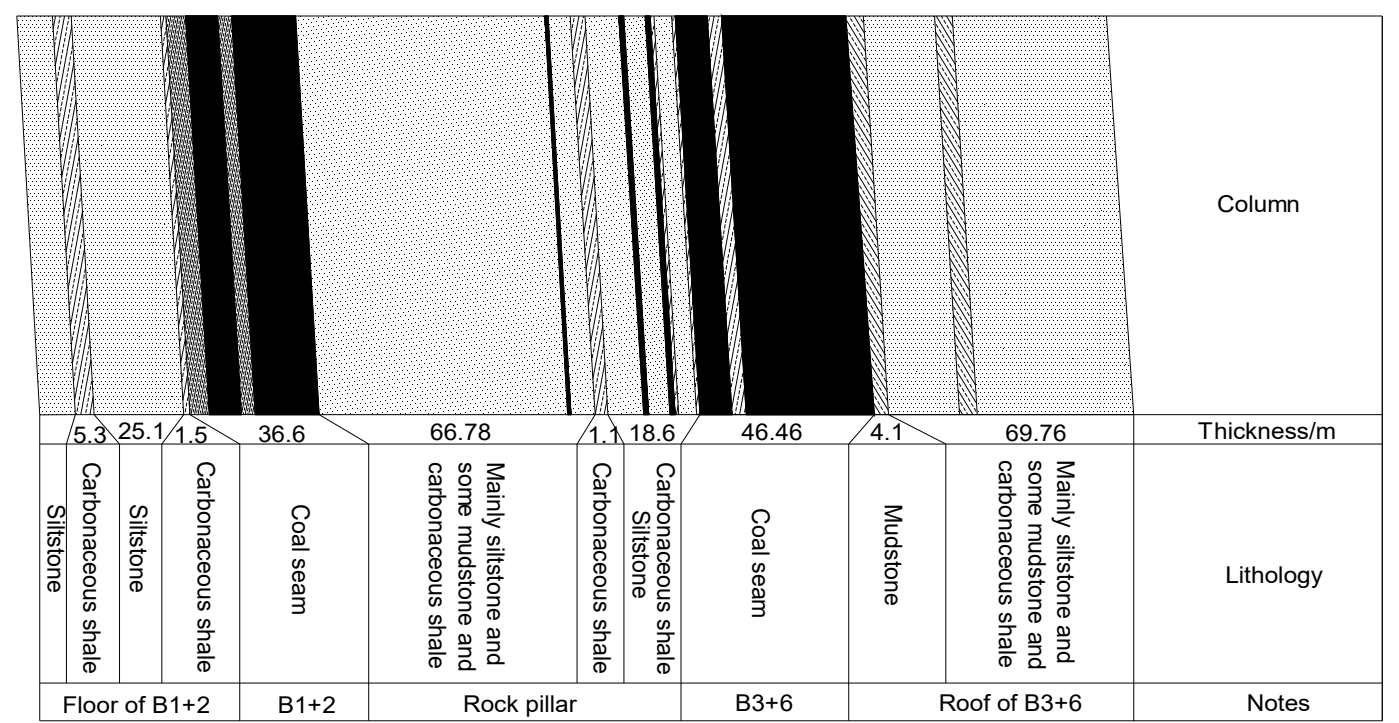

Figure 3. Distribution of the coal seams and rock (modified according to He et al. [39]. (Reproduced from [39], Elsevier: 2019.).

The rockburst liability of coal refers to the property of the coal body that accumulates deformation energy and produces rockburst damage. This intrinsic factor leads to rockbursts. The dynamic failure 
time $(D T)$, burst energy index $\left(K_{E}\right)$, elastic energy index $\left(W_{E T}\right)$ and compressive strength $\left(R_{C}\right)$ were the main indexes used to evaluate the rockburst liability in this paper. A YAW-600 microcomputer-controlled electro-hydraulic servo pressure testing machine (Jinan Times Trial Instrument Co., Ltd., Jinan City, Shandong Province, China) was used for the uniaxial compression experiments. The testing machine has a maximum force of $6 \times 10^{5} \mathrm{~N}$, a load resolution of $3 \mathrm{~N}$ and a displacement resolution of $3 \times 10^{7} \mathrm{~m}$. The standard cylindrical specimens have a height of $0.1 \mathrm{~m}$ and a diameter of $0.05 \mathrm{~m}$. Parameters of the $R_{C}$ and $D T$ were measured in the same group of specimens until the coal specimen was damaged with a loading rate of $1 \times 10^{9} \mathrm{~Pa} / \mathrm{s}$. $W_{E T}$ was tested by cyclic loading with the loading rate of $1 \times 10^{9} \mathrm{~Pa} / \mathrm{s}$. When the load reaches $75-85 \%$ of the average failure load, the load is unloaded to $1-5 \%$ of the average failure load at the same rate. In this way, the load and unloading are repeated until the coal specimen is damaged. $K_{E}$ is determined by uniaxial compression tests when the loading rate is $1.0 \times 10^{-8} \mathrm{~m} / \mathrm{s}$ until the coal specimen is damaged. Each test group contained five specimens, and the average test value of the five specimens was taken for each parameter measurement result. For the calculation details of each index, please refer to Guo et al. [14]. The results of the experiment are as shown in Table 1. These results indicate that the No. B3 +6 coal seam has a weak rockburst liability, meaning that it has the capacity to store energy and is prone to dynamic breakage. The mechanical properties (unit weight $\gamma$, compressive strength, tensile strength $\sigma_{t}$, elasticity modulus $E$, Poisson's ratio $v$ and cohesion $c$ ) of the coal and roof are shown in Table 2. The uniaxial compressive strength of the roof is $8.24 \times 10^{7} \mathrm{~Pa}$ and has a medium rockburst liability.

Table 1. Rockburst liability test parameters of the No. B3 +6 coal seam.

\begin{tabular}{ccccc}
\hline $\begin{array}{c}\text { Dynamic Failure } \\
\text { Time } D T \text { (s) }\end{array}$ & $\begin{array}{c}\text { Burst Energy } \\
\text { Index } K_{E}\end{array}$ & $\begin{array}{c}\text { Elastic Energy } \\
\text { Index } W_{E T}\end{array}$ & $\begin{array}{c}\text { Compressive } \\
\text { Strength } \boldsymbol{R}_{C} \text { (Pa) }\end{array}$ & $\begin{array}{c}\text { Type of Rock } \\
\text { Burst Liability }\end{array}$ \\
\hline 0.14 & 2.08 & 5.86 & $1.24 \times 10^{6}$ & Weak \\
\hline
\end{tabular}

Table 2. Mechanical properties of the coal and roof.

\begin{tabular}{ccccccc}
\hline Strata Name & $\begin{array}{c}\text { Unit Weight } \\
\boldsymbol{\gamma}\left(\mathbf{N} \cdot \mathbf{m}^{-\mathbf{3}}\right)\end{array}$ & $\begin{array}{c}\text { Compressive } \\
\left.\text { Strength } \boldsymbol{R}_{\boldsymbol{C}} \mathbf{( P a}\right)\end{array}$ & $\begin{array}{c}\text { Tensile Strength } \\
\boldsymbol{\sigma}_{t} \mathbf{( P a )}\end{array}$ & $\begin{array}{c}\text { Elasticity } \\
\text { Modulus } \boldsymbol{E}(\mathbf{P a})\end{array}$ & $\begin{array}{c}\text { Poisson's } \\
\text { Ratio } \boldsymbol{v}\end{array}$ & $\begin{array}{c}\text { Cohesion } \\
\boldsymbol{c}(\mathbf{P a})\end{array}$ \\
\hline Coal & $1.31 \times 10^{4}$ & $1.24 \times 10^{7}$ & $1.21 \times 10^{6}$ & $2.12 \times 10^{9}$ & 0.21 & $2.42 \times 10^{6}$ \\
Rock (roof) & $2.76 \times 10^{4}$ & $8.24 \times 10^{7}$ & $5.78 \times 10^{6}$ & $2.7 \times 10^{10}$ & 0.28 & $7.01 \times 10^{6}$ \\
\hline
\end{tabular}

\subsection{Analysis of the Rockburst Event}

On 1 February 2017, a rockburst occurred in the headentry and tailentry in the No. B3 + 6 coal seam at the +450 horizontal level when the mining length is $648 \mathrm{~m}$. The released energy of the captured MS event corresponding to the rockburst source is $2.1 \times 10^{8} \mathrm{~J}$, causing serious damage to the roadway. Some of the site damage photos are shown in Figure 4. The statistical results of the damage type and degree of rockburst are shown in Table 3. The damage degree of the headentry is greater than that of the tailentry, which may be closely pertinent to the instability and fracturing of the steeply inclined suspended roof, as the headentry is close to the suspended roof. The damage could be mainly characterized by floor heave, the sidewall's inward deformation, subsidence of the roadway shoulder and the roof subsidence. Simultaneously, the failure shows the directionality from roof side to coal side, which reveals that the instability of the suspended roof is one of the main factors causing rockbursts in SIETCS.

From the above analysis and in conjunction with other roadway deformation observations, we conclude the following main characteristics of rockburst in SIETCS: (1) There is no obvious periodicity from the rockbursts' occurrence time records. (2) The deformation of the headentry during the mining period is more frequent and severe than that of the tailentry. (3) The equipment moved from roof side to coal side under the dynamic shock. The deformation of headentry could be mainly characterized by the sidewall's inward deformation, subsidence of the roadway shoulder and the 
roof movement and appearance of a string bag. The deformation of the tailentry mainly included the sidewall's inward deformation and floor heave.

a

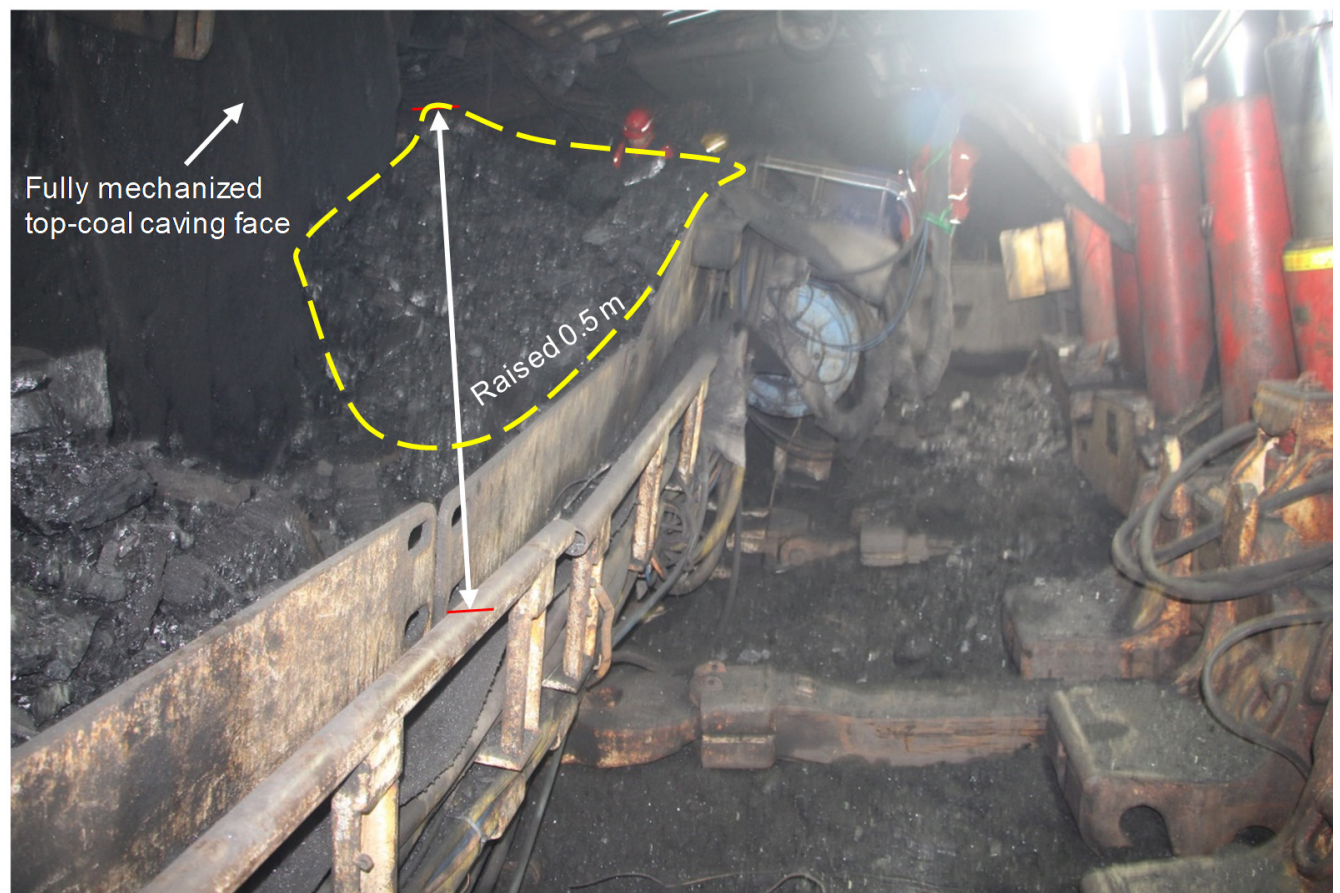

b

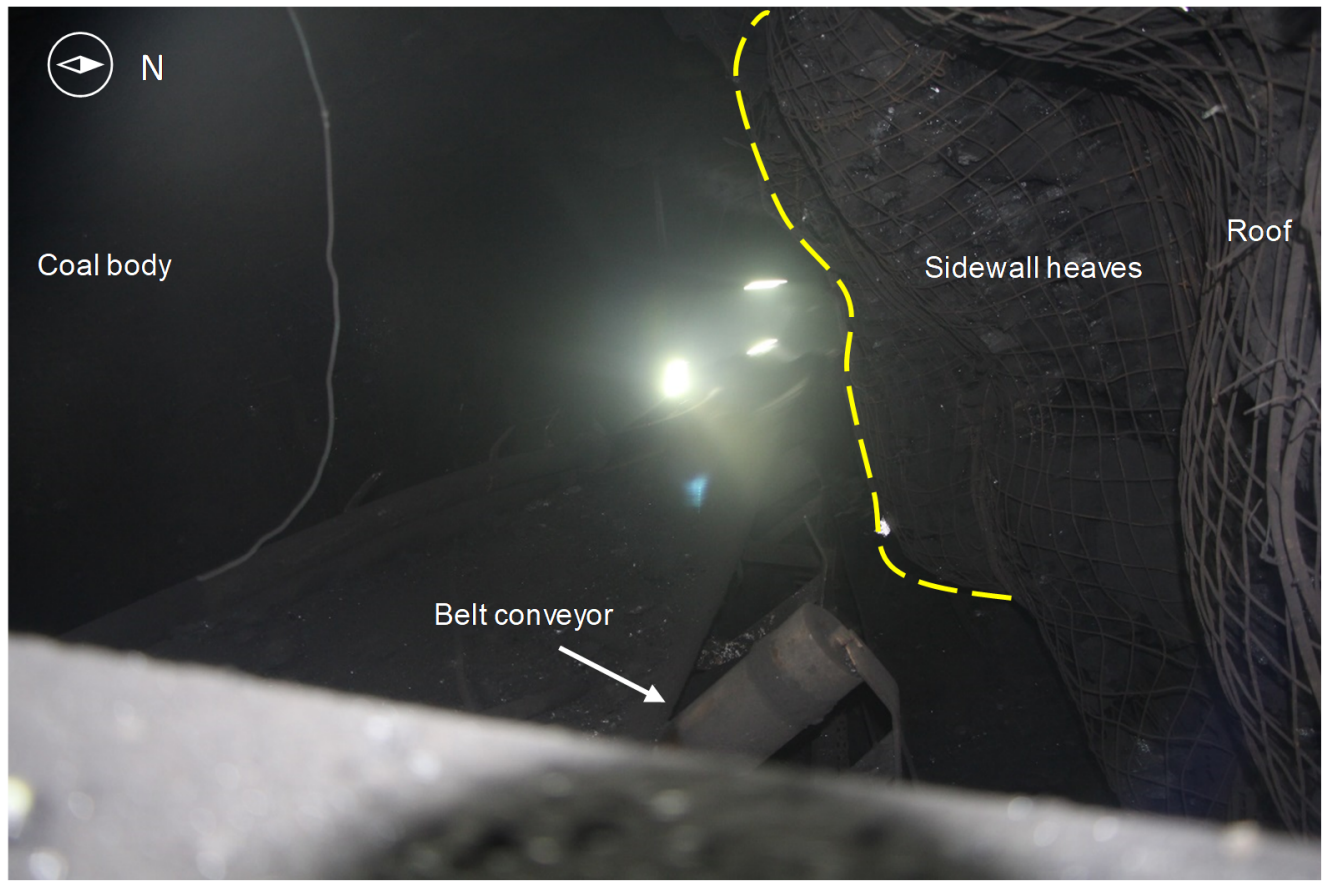

Figure 4. Cont. 
c

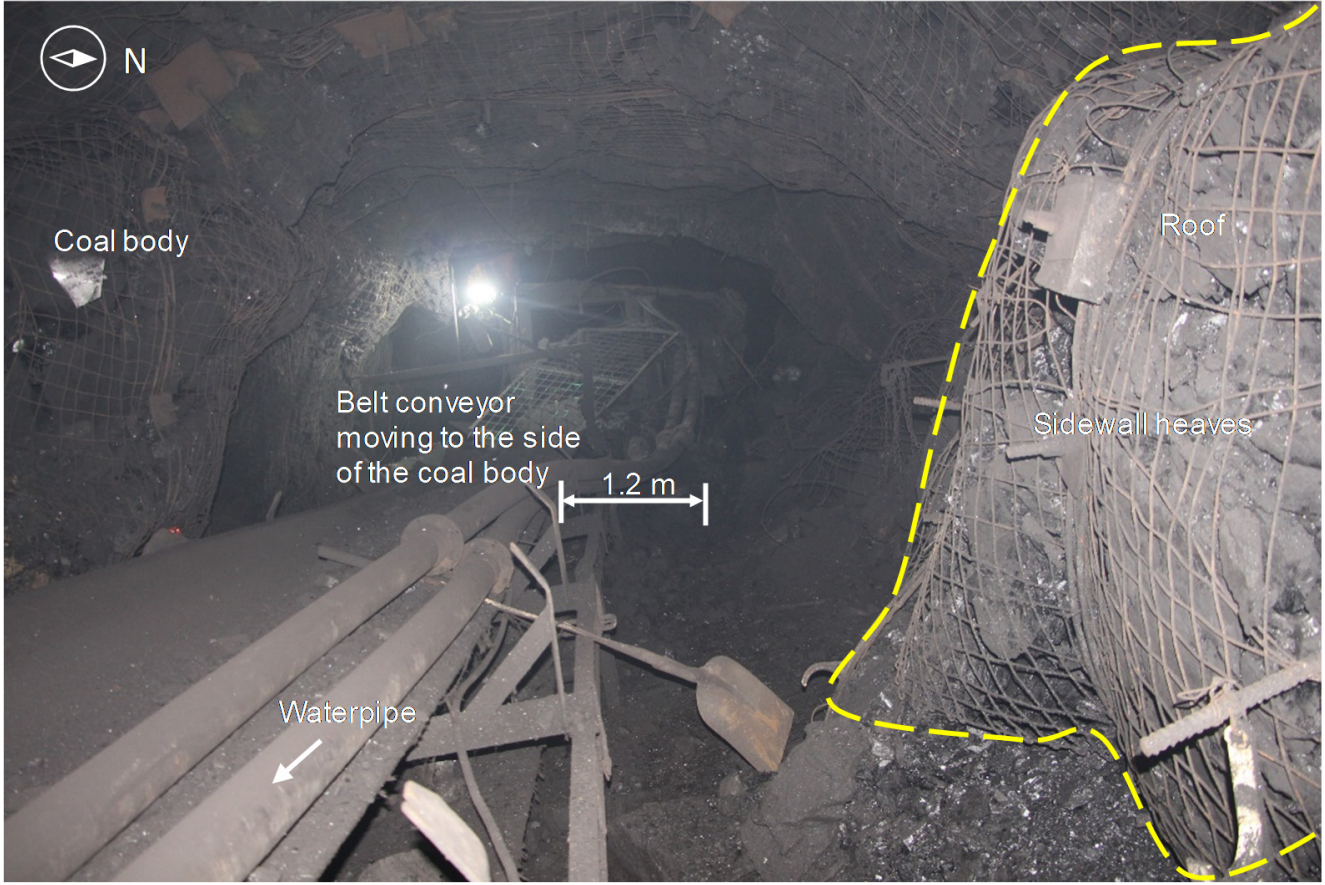

d

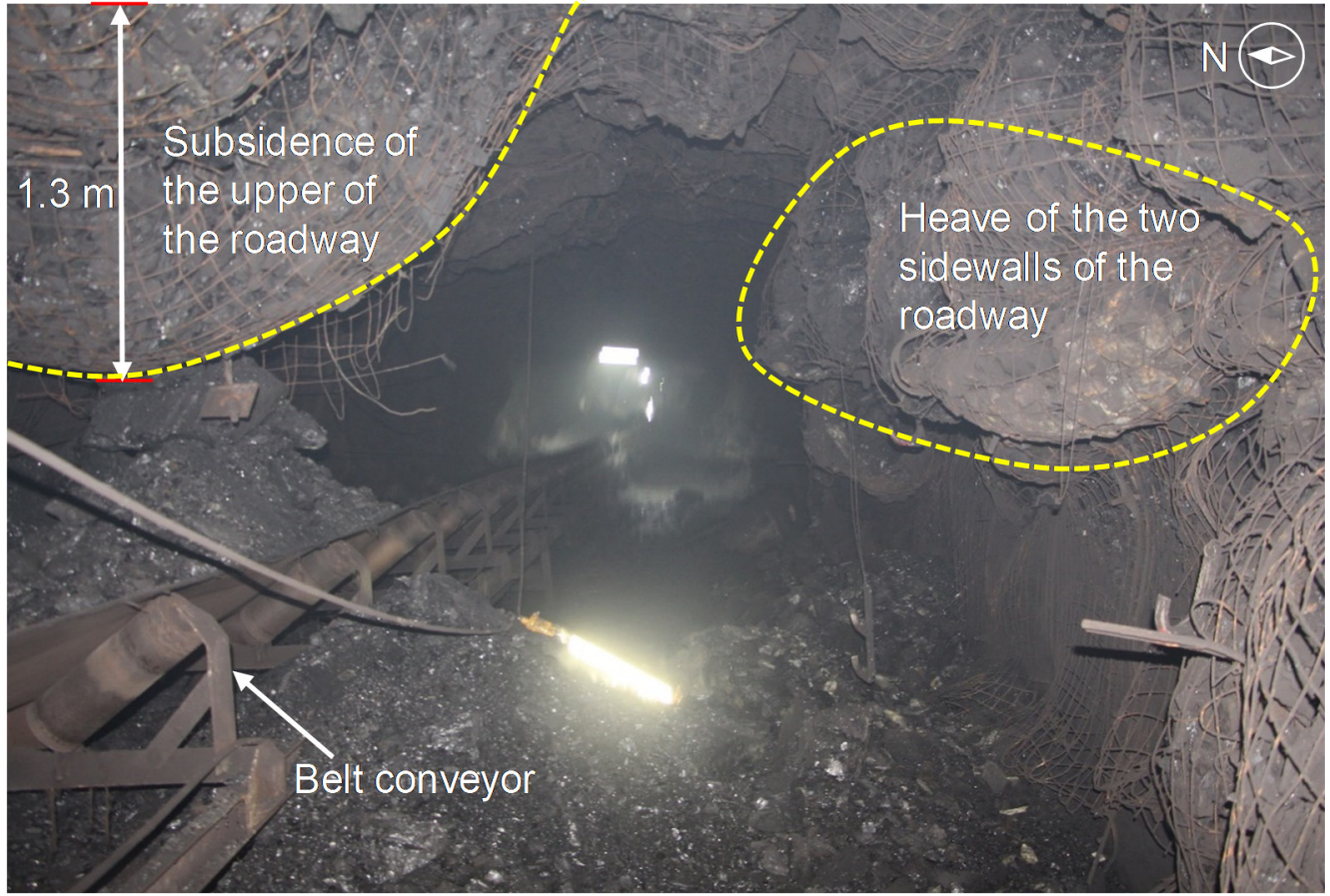

Figure 4. Damage caused by the rockburst: (a) floor heave; (b) sidewall heave; (c) belt conveyor moving to the side of the coal body and sidewall heave; (d) subsidence of the upper part of the roadway. 
Table 3. Damage type and scope of rockburst that occurred on 1 February 2017.

\begin{tabular}{ccccccc}
\hline Roadway & $\begin{array}{c}\text { Damage } \\
\text { Length }(\mathrm{m})\end{array}$ & $\begin{array}{c}\text { Roof } \\
\text { Subsidence } \\
(\mathbf{m})\end{array}$ & $\begin{array}{c}\text { Floor } \\
\text { Heave } \\
(\mathbf{m})\end{array}$ & $\begin{array}{c}\text { North Wall } \\
\text { of Roadway } \\
\text { Heave }(\mathbf{m})\end{array}$ & $\begin{array}{c}\text { South Wall } \\
\text { of Roadway } \\
\text { Heave }(\mathbf{m})\end{array}$ & Description (Main Damage) \\
\hline Headentry & 194 & $0.7-1$ & - & $0.5-1.3$ & $0.3-0.7$ & $\begin{array}{c}\text { Roof moved: roof subsidence and the } \\
\text { appearance of a string bag with a size of } \\
2 \times 2 \times 1 \mathrm{~m} \text {, belt conveyor moved from } \\
\text { roof side to coal side and damage to the } \\
\text { hydraulic prop. }\end{array}$ \\
Tailentry & 18 & - & 0.2 & $0.3-0.5$ & - & $\begin{array}{c}\text { Lower wall moved } 0.3-0.5 \mathrm{~m} \text {, floor } \\
\text { heaved } 0.2 \mathrm{~m} \text { and damage to the } \\
\text { hydraulic props. }\end{array}$ \\
\hline
\end{tabular}

\section{Rockburst Mechanism Analysis}

The analysis of the damage characteristics of rockburst in Section 2.2 shows that under the condition of gob filling, the damage characteristics of a rockburst in SIETCS shows an obvious directionality from roof side to coal side. The forces that caused these directional damage characteristics may come from the suspended roof. Therefore, in this section, the mechanical model and EDE distribution function of a "steeply inclined suspended roof structure" have been developed to research the stresses acting on the roof and EDE distribution. Simultaneously, the influence factors of the EDE were theoretically analyzed, and the rockburst risk assessment is carried out based on the theory of rockburst start-up to reveal the rockburst mechanism of the SIETCS. The more detailed analysis is as below.

\subsection{Mechanical Model of the "Steeply Inclined Suspended Roof Structure"}

A physical model of a "steeply inclined suspended roof structure" shown in Figure 5 is established, considering the high horizontal tectonic stress and the weight of the overlying strata. The lower part of the suspended roof extends from the working surface to the coal body, so it can be regarded as a fixed end. After the coal seam is mined, the plastic zone of the coal body has a supporting force on the roof. To facilitate the study of the influence of the above-mentioned several forces on the roof, this paper does not consider the self-weight of the roof and establishes the mechanical model of the "steeply inclined suspended roof structure" as shown in Figure 6.

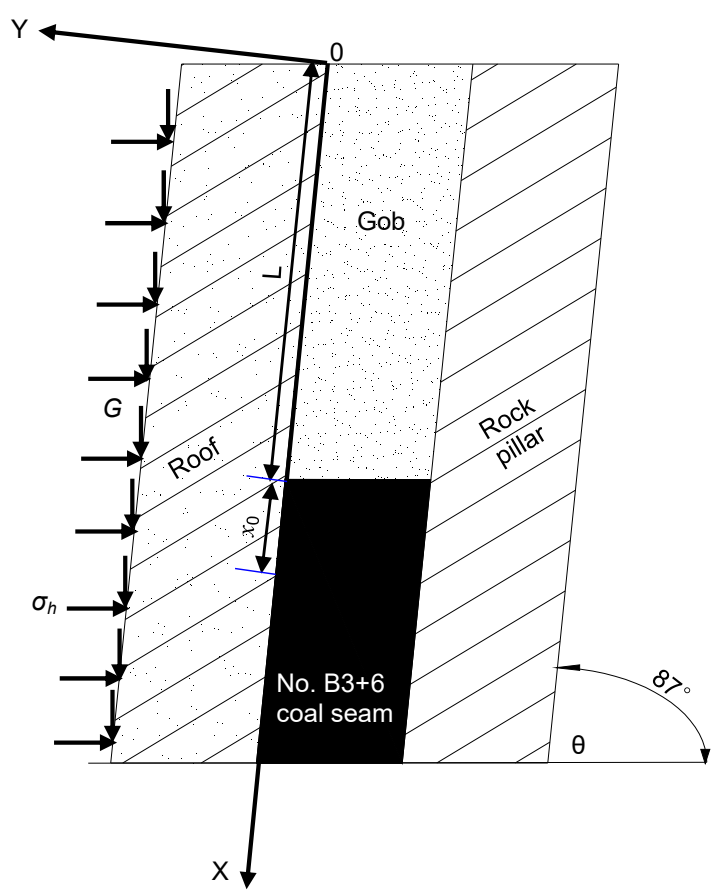

Figure 5. Physical model of the "steeply inclined suspended roof structure". 


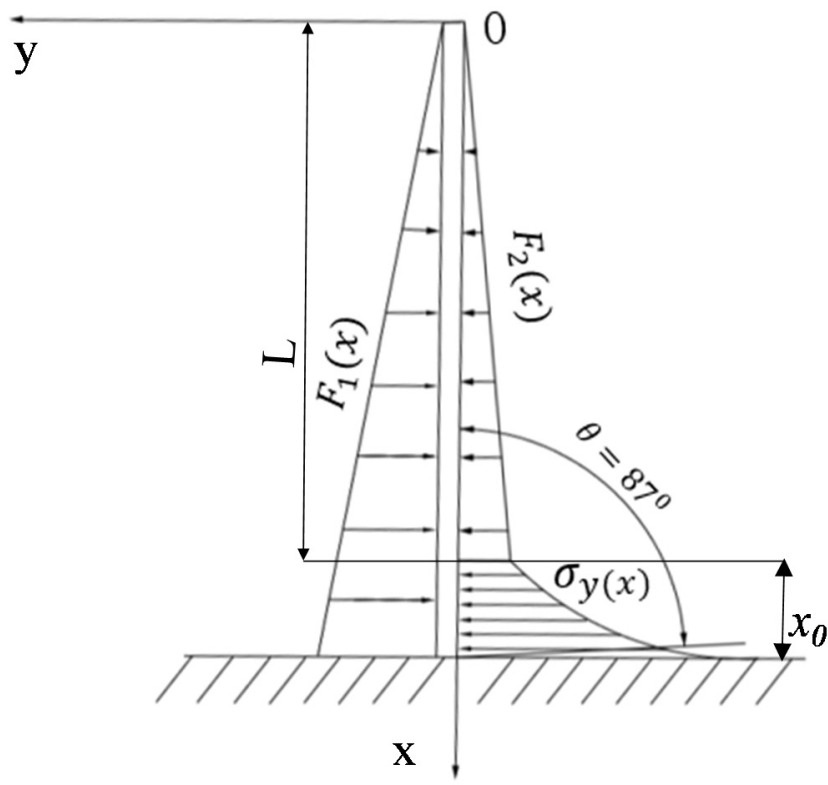

Figure 6. Mechanical model of the "steeply inclined suspended roof structure".

SIETCS is mined from the surface to the deep, and the coordinate system is established as shown in Figure 6 with the end point of the surface roof as the origin, and $x$ is the length of the roof extending to underground. The left side of the roof is affected by the horizontal tectonic stress $\sigma_{h}$ and the gravity load of the overlying strata $G$, which can be simplified as the load $F_{1}(x)$ that is perpendicular to the inclined direction of the coal seam. According to the study of the in situ stress, the horizontal tectonic stress $\sigma_{h}$ is A times the load of the overlying strata $G$, and $\sigma_{h}=A \gamma x \sin \theta$ as the load on the roof along the $x$-axis passes through the roof section perpendicular to the $y$-axis; the bending moment is zero, so the axial load is not considered. Assuming that the width of the roof at any section is the unit length, the expression of the load on the top of the roof at any section is expressed as Equation (1):

$$
F_{1}(x)=\gamma x \sin \theta(A \sin \theta+\cos \theta),\left(0 \leq x \leq L+x_{0}\right)
$$

where $\gamma$ is the average unit weight of the overlying strata, and $\theta$ is the dip angle of the coal seam.

To calculate the supporting force $\sigma_{y}$ of the plastic zone of the coal body to the roof, the expression of the stress and width in the plastic zone can be used [40]. The supporting force $\sigma_{y}(x)$ in the plastic zone which is along the y-axis to the roof is expressed as Equation (2):

$$
\sigma_{y}(x)=\left(\frac{c}{\tan \varphi}+\frac{P_{X}}{\lambda}\right) e^{\frac{2 \tan \varphi}{\lambda m}(x-L)}-\frac{c}{\tan \varphi}
$$

where $\lambda$ is the lateral pressure coefficient, which is the ratio of vertical stress to horizontal stress. $m$ is the thickness of the coal seam. $c$ is the cohesion of the coal-rock interface. $\varphi$ is the internal friction angle of the coal-rock interface, $L$ is the length of the roof and $P_{X}$ is the supporting force of the loess to the coal. In fact, the compaction degree of the loess is different in different positions. Therefore, the expression of the $P_{X}$ is expressed as Equation (3):

$$
P_{X}=k \gamma_{1} L \sin ^{2} \theta
$$

where $\gamma_{1}$ is the unit weight of loess, $k$ is the supporting force coefficient, and the value is between 0 to 1. The larger the value is, the more compact the filling is and $k=1$, which means that the supporting force of the compacted loess on the roof reaches its maximum; when the filled loess has no supporting effect on the roof completely, $k=0$. 
The plastic zone width $x_{0}$ of the coal body is:

$$
x_{0}=\frac{\lambda m}{2 \tan \varphi} \operatorname{In}\left(\frac{n F_{1}(L)+\frac{c}{\tan \varphi}}{\frac{c}{\tan \varphi}+\frac{k \gamma_{1} L \sin ^{2} \theta}{\lambda}}\right)
$$

where $I$ is the moment of inertia, and $n$ is the stress concentration factor.

The interface of coal and loess is at $x=L$, and it is considered that the supporting force of the coal body to the roof is equal to that of the loess to the roof:

$$
\sigma_{y}(L)=F_{2}(L)=\frac{k \gamma_{1} L \sin ^{2} \theta}{\lambda}
$$

The backfilling range of loess is from $x=0$ to $x=L$. When $x=0$, the supporting force of the loess to the roof is zero. Therefore, to simplify the problem, the supporting force of the loess to the roof is considered to be the load linearly increasing along the $\mathrm{x}$-axis. It is concluded that the supporting load $F_{2}(x)$ is:

$$
F_{2}(x)=\frac{k \gamma_{1} \sin ^{2} \theta x}{\lambda}
$$

\subsection{EDE Analysis of the Roof}

The mechanical model of the "steeply inclined suspended roof structure" (Figure 6) described above is then simplified. The roof is simplified into a cantilever beam, which is subjected to the loads of $F_{1}(x), F_{2}(x)$ and $\sigma_{y}(x)$ at different locations.

According to the load distribution, the bending moment function $M(x)$ at any $x$ of the beam is as shown in Equation (7):

$$
M(x)=\left\{\begin{array}{l}
\frac{\gamma x^{3} \sin \theta(A \sin \theta+\cos \theta)}{6}-\frac{k \gamma_{1} \sin ^{2} \theta x^{3}}{6 \lambda} \\
(0 \leq x \leq L) \\
\frac{\gamma x^{3} \sin \theta(A \sin \theta+\cos \theta)}{6}-\frac{k \gamma_{1} \sin ^{2} \theta L^{2}\left(x-\frac{2}{3} L\right)}{2 \lambda}-\left(\frac{\lambda m}{2 \tan \varphi}\right)^{2}\left(\frac{c}{\tan \varphi}+\frac{k \gamma_{1} L \sin ^{2} \theta}{\lambda}\right)\left(e^{\frac{2 \tan \varphi(x-L)}{\lambda m}}-1\right) \\
+\frac{\lambda m}{2 \tan \varphi}\left(\frac{c}{\tan \varphi}+\frac{k \gamma_{1} L \sin ^{2} \theta}{\lambda}\right)(x-L)+\frac{c(x-L)^{2}}{2 \tan \varphi} \\
\left(L<x \leq L+x_{0}\right)
\end{array}\right.
$$

According to the relationship between bending moment and EDE, the expression of EDE at any $x$ of the roof can be expressed as Equation (8):

$$
U(x)=\left\{\begin{array}{l}
\frac{1}{2 E I}\left[\frac{\gamma x^{3} \sin \theta(A \sin \theta+\cos \theta)}{6}-\frac{k \gamma_{1} \sin ^{2} \theta x^{3}}{6 \lambda}\right]^{2} \\
(0 \leq x \leq L) \\
\frac{1}{2 E I}\left[\begin{array}{cc}
\frac{\gamma x^{3} \sin \theta(A \sin \theta+\cos \theta)}{6}-\frac{k \gamma_{1} \sin ^{2} \theta L^{2}\left(x-\frac{2}{3} L\right)}{2 \lambda}-\left(\frac{\lambda m}{2 \tan \varphi}\right)^{2}\left(\frac{c}{\tan \varphi}+\frac{k \gamma_{1} L \sin ^{2} \theta}{\lambda}\right)\left(e^{\frac{2 \tan \varphi(x-L)}{\lambda m}}-1\right) \\
\left(L<x \leq L+x_{0}\right) & +\frac{\lambda m}{2 \tan \varphi}\left(\frac{c}{\tan \varphi}+\frac{k \gamma_{1} L \sin \theta}{\lambda}\right)(x-L)+\frac{c(x-L)^{2}}{2 \tan \varphi}
\end{array}\right]^{2}
\end{array}\right.
$$

\subsection{Influence Factors of the EDE of the Overhanging Roof}

Equation (8) shows that the main influencing factors are the elastic modulus of the overhanging hard roof, the inertial moment of the overhanging hard roof, the internal friction angle of the coal-rock interface, the cohesive force of the coal-rock interface, the dip angle of the coal seam, the supporting force coefficient, the lateral pressure coefficient, the thickness of the coal seam, the mining depth, the average unit weight of the overlying strata and the unit weight of the loess.

The physical mechanical parameters of the coal seam, loess and rock strata, which were determined according to the actual field conditions of the WCM, are as follows: The elastic modulus $E$ of the 
overhanging hard roof is $2.7 \times 10^{10} \mathrm{~Pa}$. The internal friction angle $\varphi$ and the cohesive force $c$ of the coal-rock interface are $30^{\circ}$ and $10^{6} \mathrm{~Pa}$, respectively. The dip angle of the coal seam $\theta$ is $87^{\circ}$. The supporting force coefficient $k$ is 0.5 , and the lateral pressure coefficient $\lambda$ is 0.5 , while the thickness of the coal seam $m$ is $48.9 \mathrm{~m}$ and the mining depth $H$ is $400 \mathrm{~m}$. The average unit weight of the overlying strata $\gamma$ is $2.76 \times 10^{4} \mathrm{~N} / \mathrm{m}^{3}$. The unit weight of the loess $\gamma_{1}$ is $1.57 \times 10^{4} \mathrm{~N} / \mathrm{m}^{3}$. The parameters with a high correlation with the research content, such as the dip angle of the coal seam, lateral pressure coefficient and supporting force coefficient, are selected as the analysis objects to study their effects on the EDE of the roof.

\subsubsection{Analysis of Dip Angle}

The variation of the EDE with the different dip angles of the coal seam is shown in Figure 7. It can be seen that the EDE of a roof increases first and then decreases with the increasing dip angle of the coal seam. When the dip angle of the coal seam is $72.6^{\circ}$, the EDE accumulated in a roof of a given length is greater than a roof with other dip angles. Therefore, the roof in SIETCS is more easy to break and induce rockburst than that in a gently inclined and the horizontal coal seam at the same roof length under the strong mining disturbance. This result can explain the previous research results that the depth at which rockburst occurs in SIETCS is shallower than that in a horizontal or gently inclined coal seam [41]. Experiment results of the rockburst liability described in Section 2.1 show that the No. B3+ 6 coal seam has a weak rockburst liability, and the suspended roof has a medium rockburst liability. A large amount of elastic deformation accumulated in the roof with a dip angle of $87^{\circ}$ can be released instantaneously under the disturbance of mining, leading to a high possibility of inducing rockburst. On 1 February 2017, a serious rockburst occurred when the mining depth was only $300 \mathrm{~m}$. Therefore, the dip angle of the coal seam should also be taken as an important consideration when conducting the rockburst risk assessment. Simultaneously, it can be seen from Figure 8 that the EDE increases with the increasing suspended length of the roof. Reasonably controlling the suspended roof length will reduce the risk of rockburst.

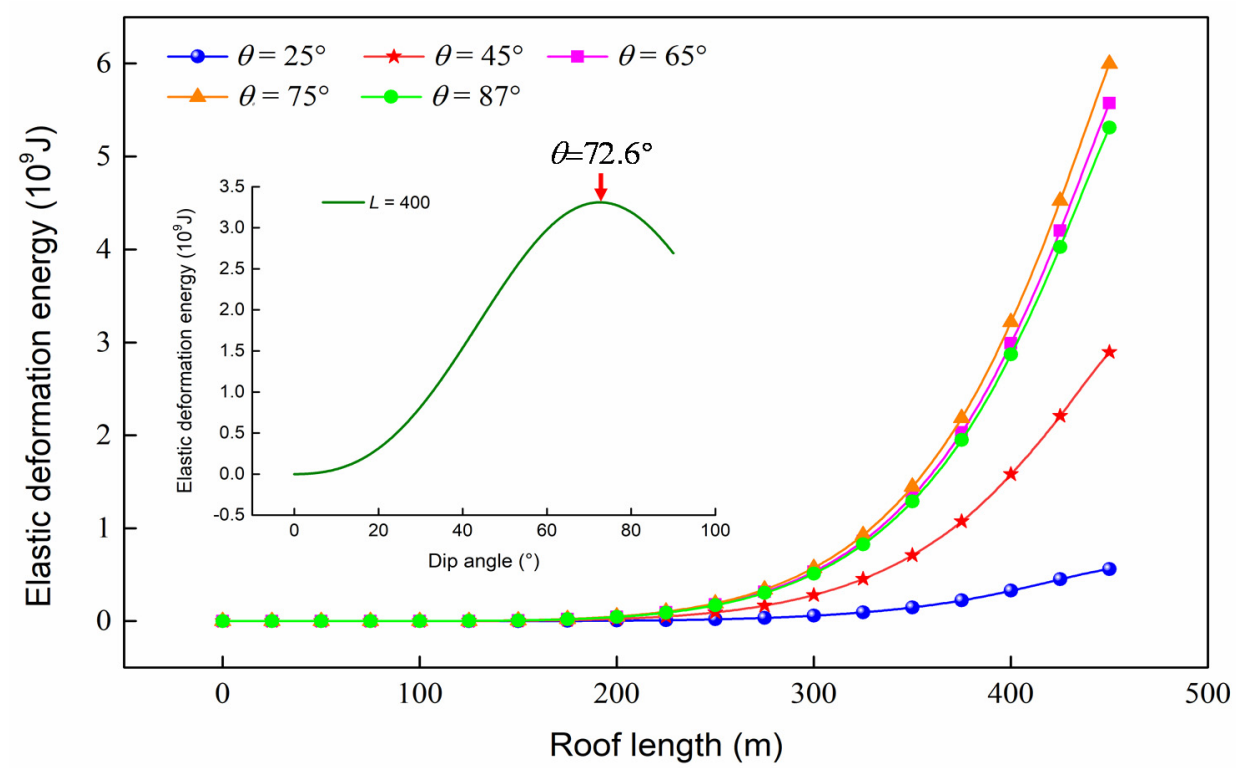

Figure 7. Distribution of the elastic deformation energy (EDE) of the roof for different dip angles of coal seams.

\subsubsection{Analysis of Lateral Pressure Coefficient}

The lateral pressure coefficient refers to the ratio of vertical to horizontal geostresses. As shown in Figure 8, the EDE of the roof increases with the decreasing of the lateral pressure coefficient. When the suspended roof length reaches a certain value, the increase of the EDE becomes larger with the 
increasing suspended roof length. The smaller the lateral pressure coefficient, the greater the increase of the EDE. This is because, when the lateral pressure coefficient is small, the horizontal stress is relatively high and the horizontal geostress is close to perpendicular to the suspended roof, which makes the roof bend towards the gob. The greater the horizontal stress, the more obvious the bending effect exists. This leads to an EDE accumulation in the support area of the coal body and brings a higher possibility of the roof breakage to induce rockburst [24]. Therefore, the horizontal stress should be released as a measure to prevent rockburst in SIETCS.

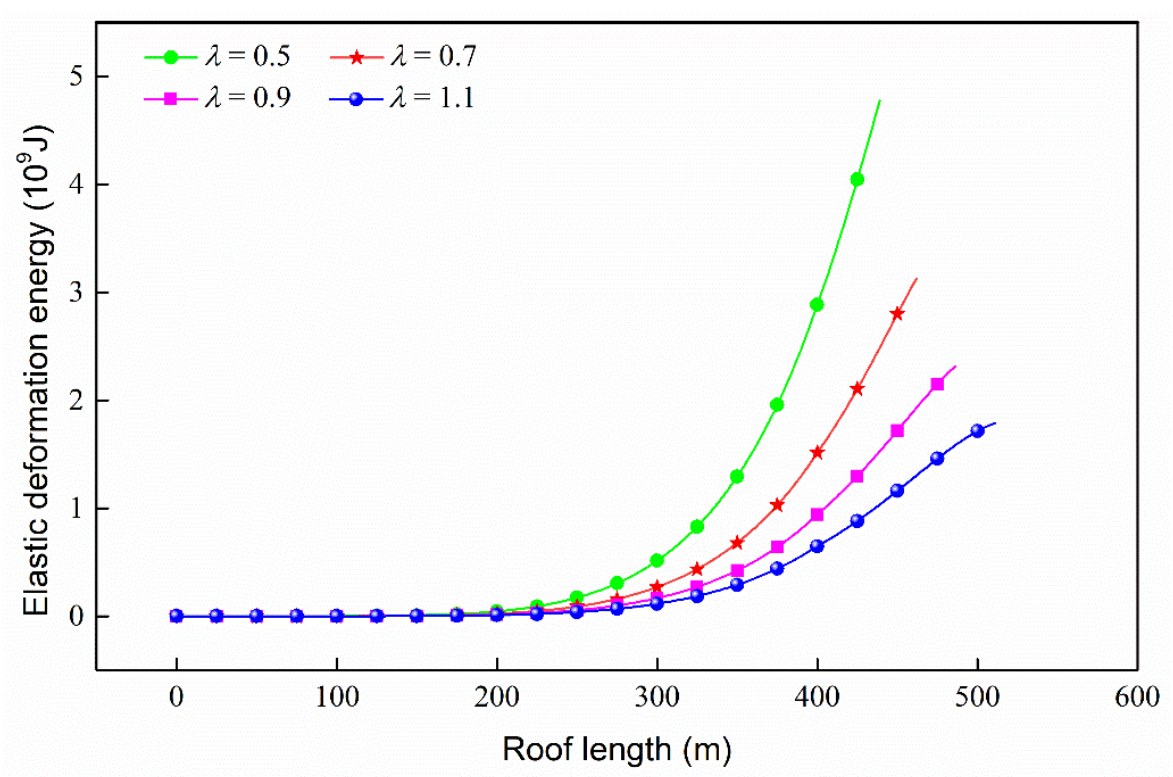

Figure 8. Variation law of the EDE of a roof with different lateral pressure coefficients.

\subsubsection{Analysis of Supporting Force Coefficient}

The variation law of the EDE of a suspended roof with the support coefficient and the suspended roof length are shown in Figure 9. The EDE of the roof of a given length increases with the decrease of the supporting force coefficients. The smaller the supporting force coefficient, the greater the increment of the EDE. This is mainly because a smaller support force coefficient means a worse filling condition of the gob. The suspended roof is more prone to bend and deform under higher horizontal stress, resulting in more concentrated stress and an EDE accumulation in the support area of the coal body. The fully mechanized top-coal caving mining method used in SIETCS usually leads to the instantaneous settlement of the loess filling the gob and a reduction of the supporting force. The instantaneous instability of the roof will induce roof breakage and release the EDE accumulated in the corresponding area, which may induce rockburst. This is an important affecting factor to induce rockburst in SIETCS, and it can be reduced by reducing the mining height and the suspended roof length. 


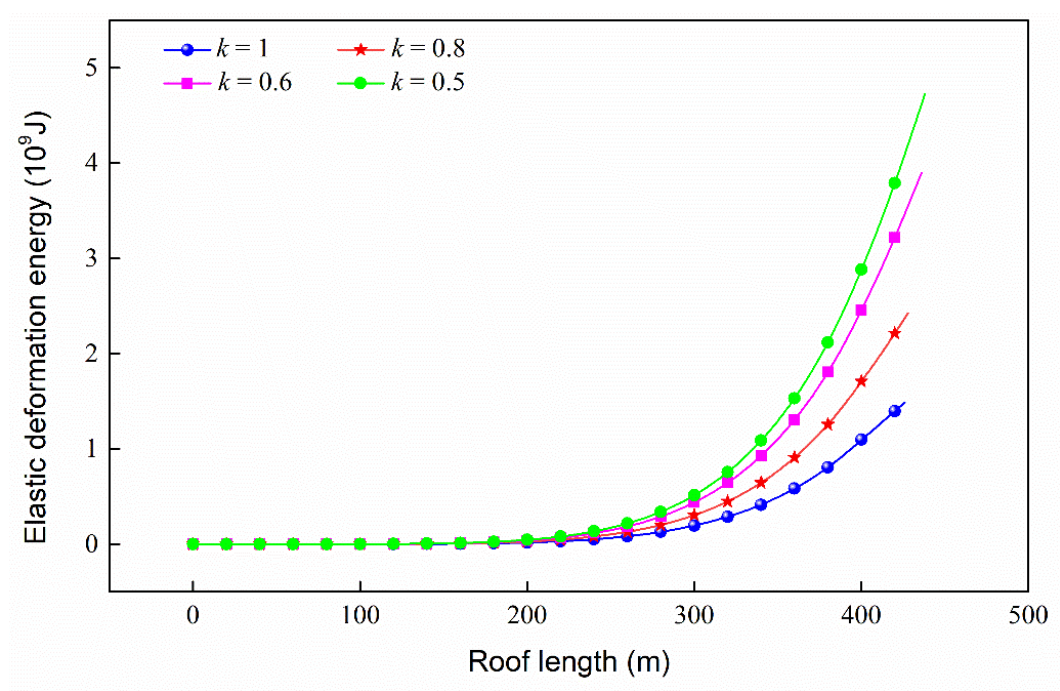

Figure 9. Variation law of the EDE of a roof with different supporting force coefficients.

\subsection{Risk Assessment for Rockbursts}

Based on the above analysis results, the risk of rockburst induced by the breakage of a suspended roof under the condition that the gob of the SIETCS is under filling conditions is evaluated by the start-up energy criterion of the rockburst. On 1 February 2017, a rockburst occurred in the +450 horizontal No. B3 +6 coal seam. The source is located on the roof at a buried depth of $340 \mathrm{~m}$. According to the distribution of the EDE of the roof calculated in Section 3.3, the EDE at this position is $2.5 \times 10^{9} \mathrm{~J}$. The energy consumption criterion of the dynamic failure of the rock mass can be calculated as follows [42]:

$$
E_{c}=R_{C}^{2} /(2 E)
$$

where $E_{c}$ is the minimum energy required for rock failure, and $R_{C}$ is the uniaxial compressive strength.

The uniaxial compressive strength and elastic modulus of the roof are shown in Table 2. According to Equation (9), the minimum energy required for roof failure is $1.3 \times 10^{5} \mathrm{~J}$, which is close to the research result of Zhang et al. [43]. This is much smaller than the EDE $\left(2.5 \times 10^{9} \mathrm{~J}\right)$ accumulated at this position according to the calculation results of Section 3.3. Therefore, the roof may be broken here even without external disturbance, because intensive energy is aggregated on the roof. Once the rockburst occurs, a larger amount of energy will be released due to the greater energy aggregation [44].

According to the superposition principle of the dynamic and static loads, the high stress concentration zone under external disturbance will induce rockburst when the coal body strength limit is exceeded. The energy of the EDE transfer from the roof rupture location to the limit equilibrium area of the coal body is calculated as follows:

$$
E_{d}=E_{d 0} R^{-\eta}
$$

where $E_{d 0}$ is the initial energy released by the roof fracture, which can be obtained by the MS monitoring system. $R$ is the distance between the roof fracture location and the limit equilibrium zone of the coal, which can be calculated by the source location. $\eta$ is the energy attenuation index of the elastic wave propagation in the coal-rock mass. The attenuation index of the complete rock is usually 0.58 [45].

MS monitoring shows that the initial energy released by the roof fracture on 1 February 2017 is $2.1 \times 10^{8} \mathrm{~J}$, and the distance between the fracture location and the limit equilibrium area of the coal wall is $60.67 \mathrm{~m}$. The $E_{d}$ calculated from Equation (10) is $1.93 \times 10^{8} \mathrm{~J}$. The minimum energy $E_{c}$ required for the failure of the coal body calculated by Equation (9) is $3.62 \times 10^{4} \mathrm{~J}$. Simultaneously, the rockburst liability test results described in Section 2.1 shows that the No. B3 +6 coal seam and roof have weak and medium rockburst liability, respectively. According to the start-up energy criterion 
of the rockburst [46]: $E_{0}+E_{d}-E_{c}>0$, and it can be known that in the compressive area of the coal body compressed by the suspended roof, the rockburst will be induced by the dynamic disturbance generated by the fracture of the roof.

According to the analysis of the rockburst, roadway failure characteristics and mechanical and EDE analysis of the roof, the mechanism of a rockburst in the No. B3 +6 coal seam is obtained, i.e., a "high compressive stress plus breakage of the suspended roof-induced stress" rockburst. The mechanism of the rockburst is consistent with the one type of rockburst mechanisms obtained by Guo et al. [14] according to the six rockbursts that occurred in Jingxi Coalfield.

\section{Verification of Rockburst Mechanisms}

\subsection{Ground Destruction}

Ground destruction before the rockburst is shown in Figure 10a,b; some cracks occurred in the roof of the No. B3 +6 coal seam. A long crack is along the strike of the working face with a width of $0.2 \mathrm{~m}$, and the height difference between the left and right sides of the crack is $0.5 \mathrm{~m}$. The splitting of the suspended hard roof towards the gob induced backfilling material subsidence, leading to the stress concentration in the corresponding area of the roof and, thus, creating conditions for the occurrence of the rockburst. After a rockburst occurred on 1 February 2017, we found that the backfilling material subsided, and a funnel-shaped fall pit appeared (see Figure 10c). This may be due to the new gob formation during the caving operation inducing the reduction of loess compactness and the instantaneous loss of support for the roof. Under the combined effects of the overlying strata load, large horizontal stress and self-weight, the roof is pulled to the gob, and the elastic deformation of the suspended roof is accumulated. Simultaneously, the large horizontal stress and the overlying strata load are applied to the coal body through the hard roof, and a static high-stress concentration is generated in the corresponding region of the compressed coal body. A rockburst may occur when the total stresses of the static and dynamic stresses in the coal induced by roof-fracturing reach a critical stress level [17]. The subsidence of the backfilling material in the gob and the splitting of the roof layer pulled to the gob indicate that the roof breakage is the main factor inducing this rockburst, which is consistent with the results of Marcak [27].

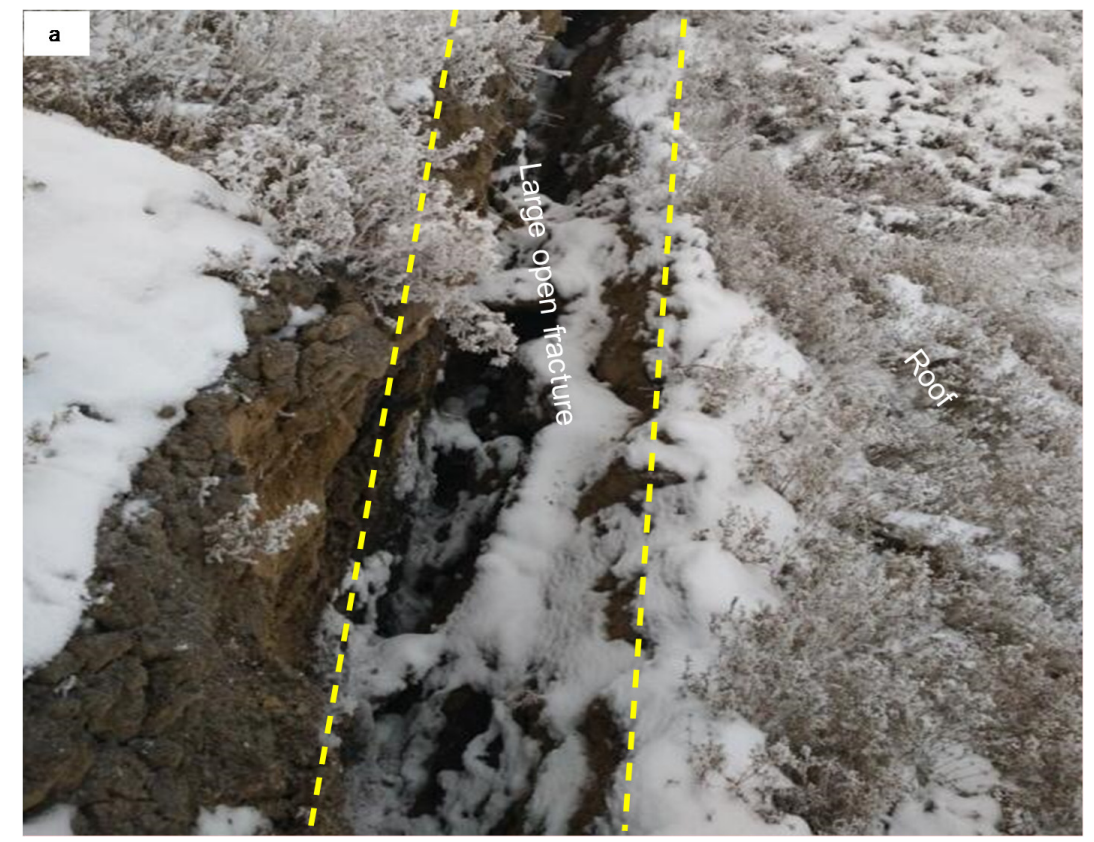

Figure 10. Cont. 

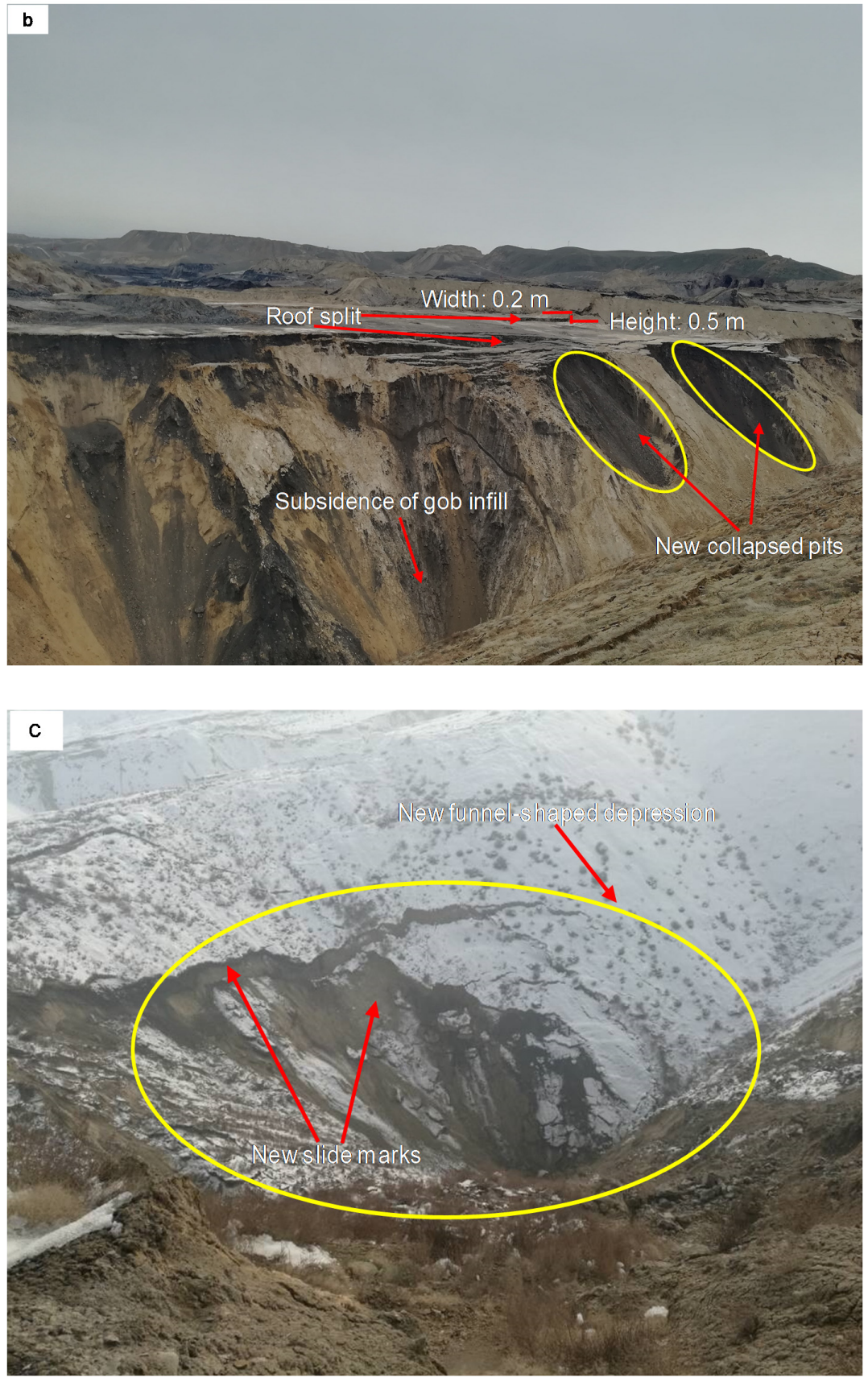

Figure 10. Ground destruction of the coal seam: (a) large open fracture of the roof; (b) roof split and subsidence of gob infill; (c) subsidence of gob infill after rockburst occurred.

\subsection{Monitoring Results of Rockburst Source}

Orlecka-Sikora [47] reported that seismic events mainly occurred in areas where stress was concentrated. The MS monitoring system can monitor the location and energy release of an MS event [48]. The MS locations can reveal the stress concentration areas [49,50]. Hence, a study of the MS events is of vital importance for the reveal of the rockburst mechanism. In this paper, the source location of the rockburst is located by the ARAMISM/E system. The MS location results are shown in Figure 11. According to the location of the source, it can be verified that the rockburst was associated with the fracturing and bending of the steeply inclined suspended roof overlying the No. B3 +6 coal seam. It can explain the phenomenon that the roadway deformation of the roof side was more serious than the coal side when the rockburst occurred. As shown in Figure 11b, the source location is at +460 
horizontal, between +475 horizontal and +450 horizontal, and above the roadway. The subsidence of the roadway shoulder and the appearance of a string bag revealed that this rockburst was related to roof breakage. The main cause of the rockburst was the dynamic stress generated by roof breakage and was superimposed with static high-stress and reached the strength limit of the coal and rock mass, inducing rockburst. The accumulated energy suddenly released into the upper roadway. This is consistent with the "high in situ stress plus high mining-induced stress" rockburst imposed by Guo et al. [14]; i.e., the rockbursts are induced by the superposition of dynamic stress caused by the roof instability and breaking and high static stress in the compressive area.
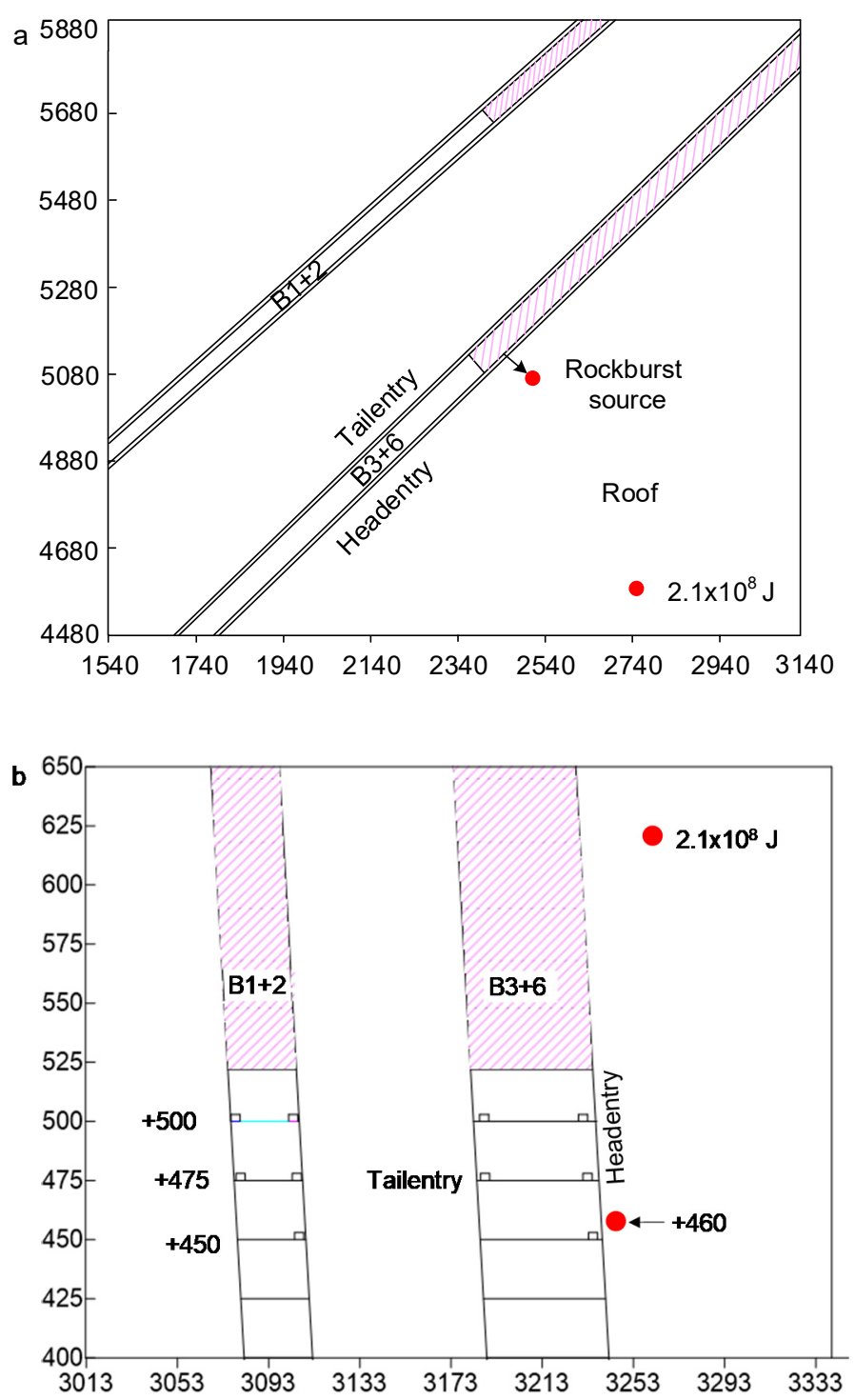

Figure 11. Location of the rockburst source that occurred on 1 February 2017: (a) plan for the source distribution and (b) elevation for the source distribution.

\subsection{Numerical Simulation Reveals the Stress Concentration Area}

To further demonstrate the rockburst risk in a SIETCS, a model was built to investigate the static stress in the suspended roof and No. B3 +6 coal seam. The model has a dimension of $600 \mathrm{~m} \times$ $2500 \mathrm{~m} \times 500 \mathrm{~m}$. The bottom of the model is a fixed surface, and the other surface is a free surface, allowing displacement. The stress boundary is applied around the four sides, and the stress increases linearly with the depth. The increase gradient is determined by the mean difference of the measured horizontal stress between +450 and +475 , and the top is applied with self-weight, as shown in 
Figure 12. The widths for the No. B3 +6 coal seam, rock pillar and No. B1 +2 coal seam are $49.6 \mathrm{~m}$, $110 \mathrm{~m}$ and $36.5 \mathrm{~m}$, respectively. Mohr-Coulomb failure criterion [51] is adopted in this research. The mechanical properties of the coal and rock are obtained from the laboratory test.

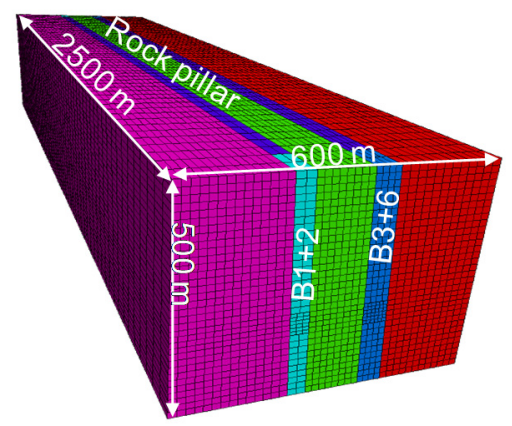

Figure 12. Model used for simulation.

The actual mining depth was simulated to research the stress distribution in No. B3 +6 with the coal seam and surrounding rock mass. Figure 13 shows that the No. B3 +6 and No. B1 +2 coal seams are mined at +450 horizontal; the peak horizontal stress is $32 \mathrm{MPa}$, located at around $50 \mathrm{~m}$ into the gob of No. B3 + 6, which is about 2.1 times the horizontal stress of this mining depth, and about 26.4 times the tensile strength of the coal. The peak horizontal stress is $30 \mathrm{MPa}$ of the roof, which is about 1.9 times the horizontal stress and about 5.2 times the tensile strength of the roof. Taking into account the dynamic disturbance arising and the lack of roof support during mining activities, the horizontal stress concentration in the coal seam and roof will further increase, easily leading to a tension failure on the roof. This demonstrates that No. B3 +6 under such a condition has a fairly high risk of rockbursts. The numerical simulation results can further verify the accuracy of the theoretically obtained rockburst mechanism of the B3 +6 coal seam.

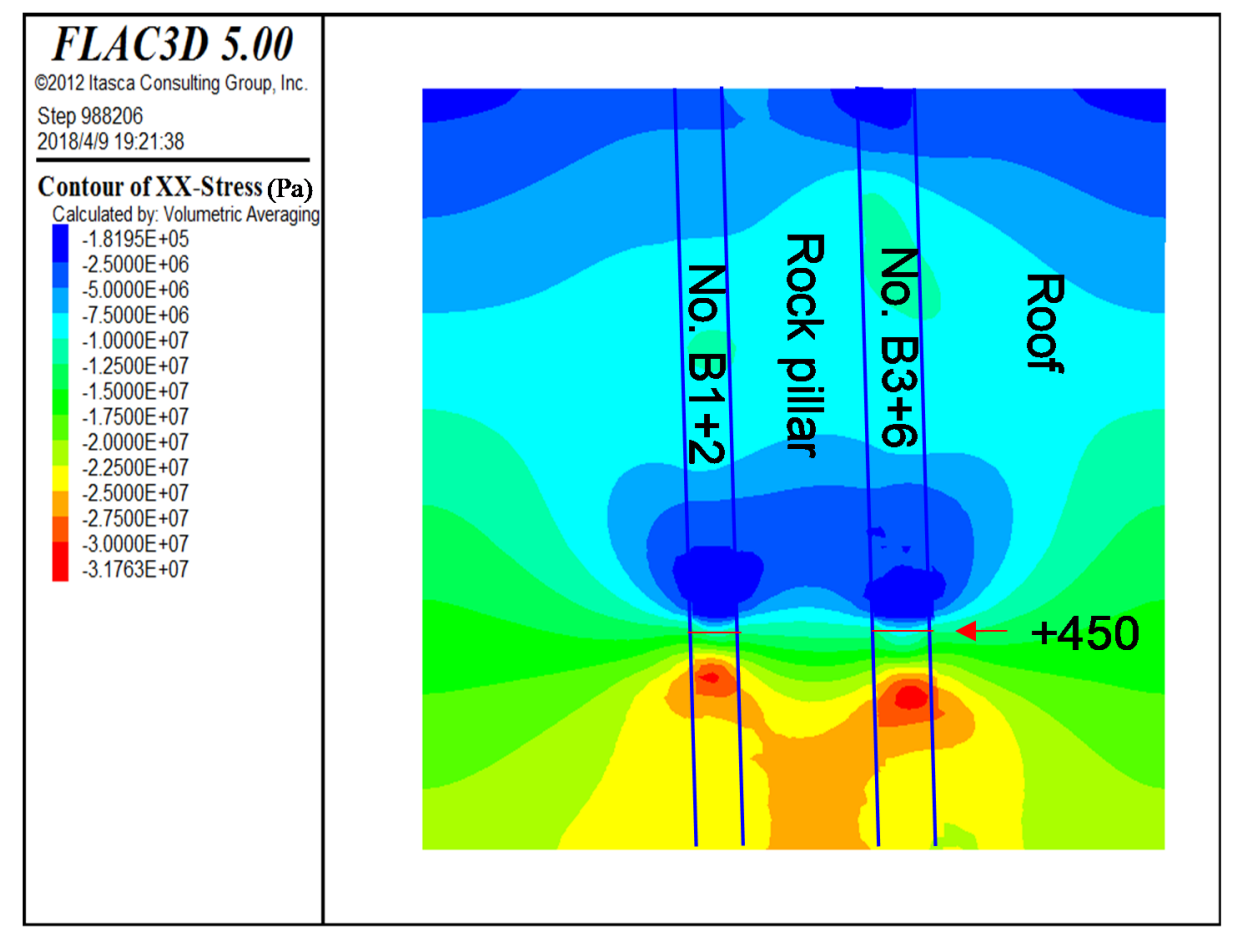

Figure 13. Horizontal stress distribution around the coal seam and rock mass. 


\section{Induced Process of Rockburst}

The top coal caving mining method is being adopted for the No. B3 +6 coal seam mining; the horizontal section height is $25 \mathrm{~m}$, and the gob above the +450 horizontal is filled with loess (Figure 14a). As shown in Figure 10b,c, the loess filled in the gob subsides instantaneously due to the large mining height of the caving mining, making the supporting force coefficient and supporting force reduce. The roof lost its support and bended towards the gob, which induced a compressive effect to the coal body at the support area (Figure 14b). The EDE of the corresponding position of the roof and coal body is increased. After bending to a certain extent, the roof was split (Figure 10a,b), and the breakage (Figures 11 and 14c) occurs in the stress concentration area, making the EDE accumulated at this position release instantaneously (Figure 13). The dynamic disturbance caused by the roof breakage propagates to the high-stress concentration area of the coal body in the lower part of the roadway, superimposed with high compressive stress. The coal body that has been around the limit equilibrium state (Figure 13) is induced the rockburst.

Combined with the rockburst damage characteristics summarized in Section 2.2, the EDE distribution of the suspended roof is calculated in Section 3. The main factors that induce the rockburst that occurred on 1 February 2017 in the WCM are the high compressive stress in the coal body caused by the roof bending and the dynamic stress during the process of the roof breakage. Simultaneously, the simulation results show that the peak horizontal stress in the compressive area is two times the horizontal stress of this mining depth and about 26.4 times the tensile strength of the coal. Therefore, the rockburst may also be induced at this location under small mining disturbances. It is of great significance to release the stress in the compressive area reasonably for the prevention and control of rockbursts in this coal seam.

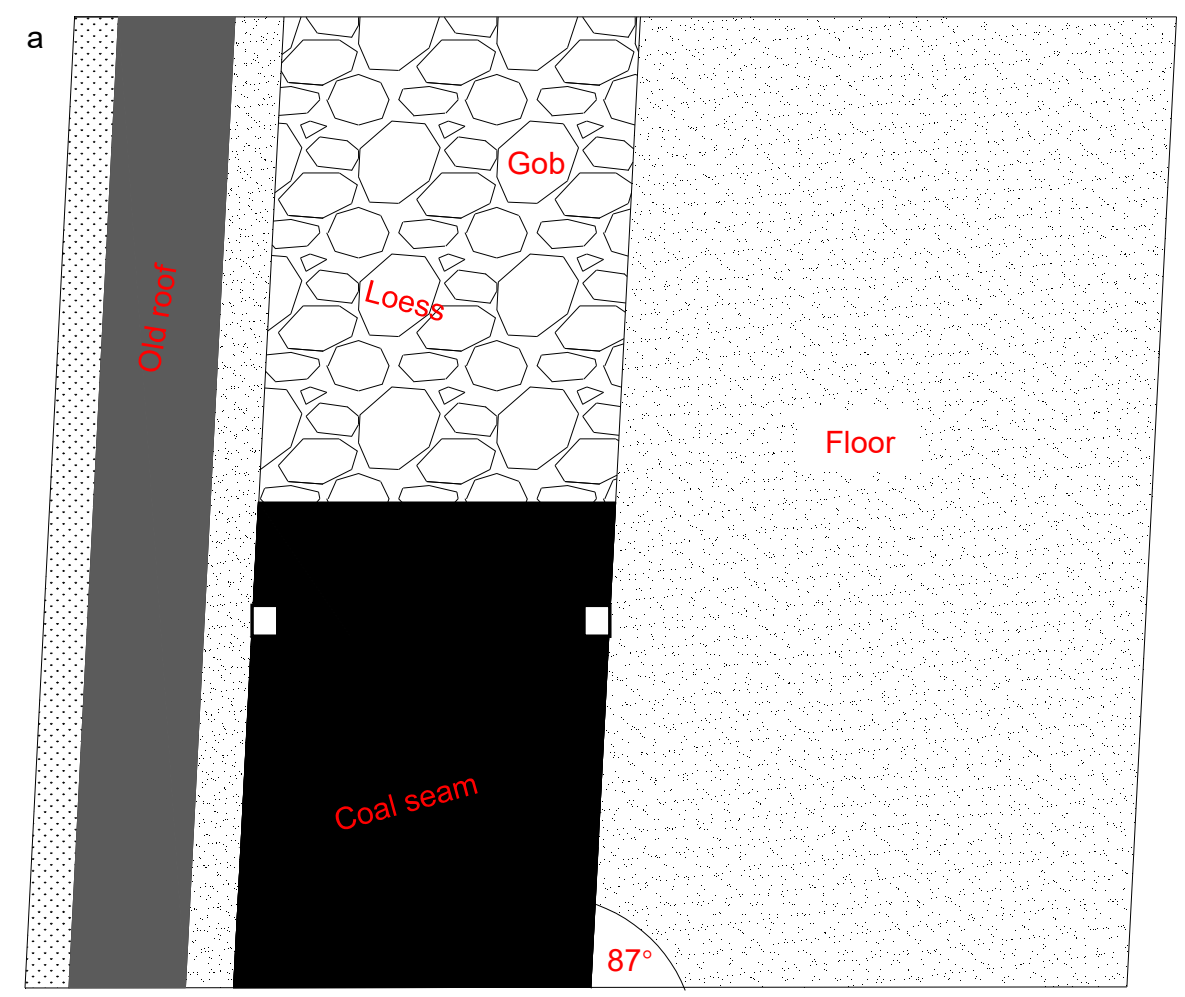

Figure 14. Cont. 

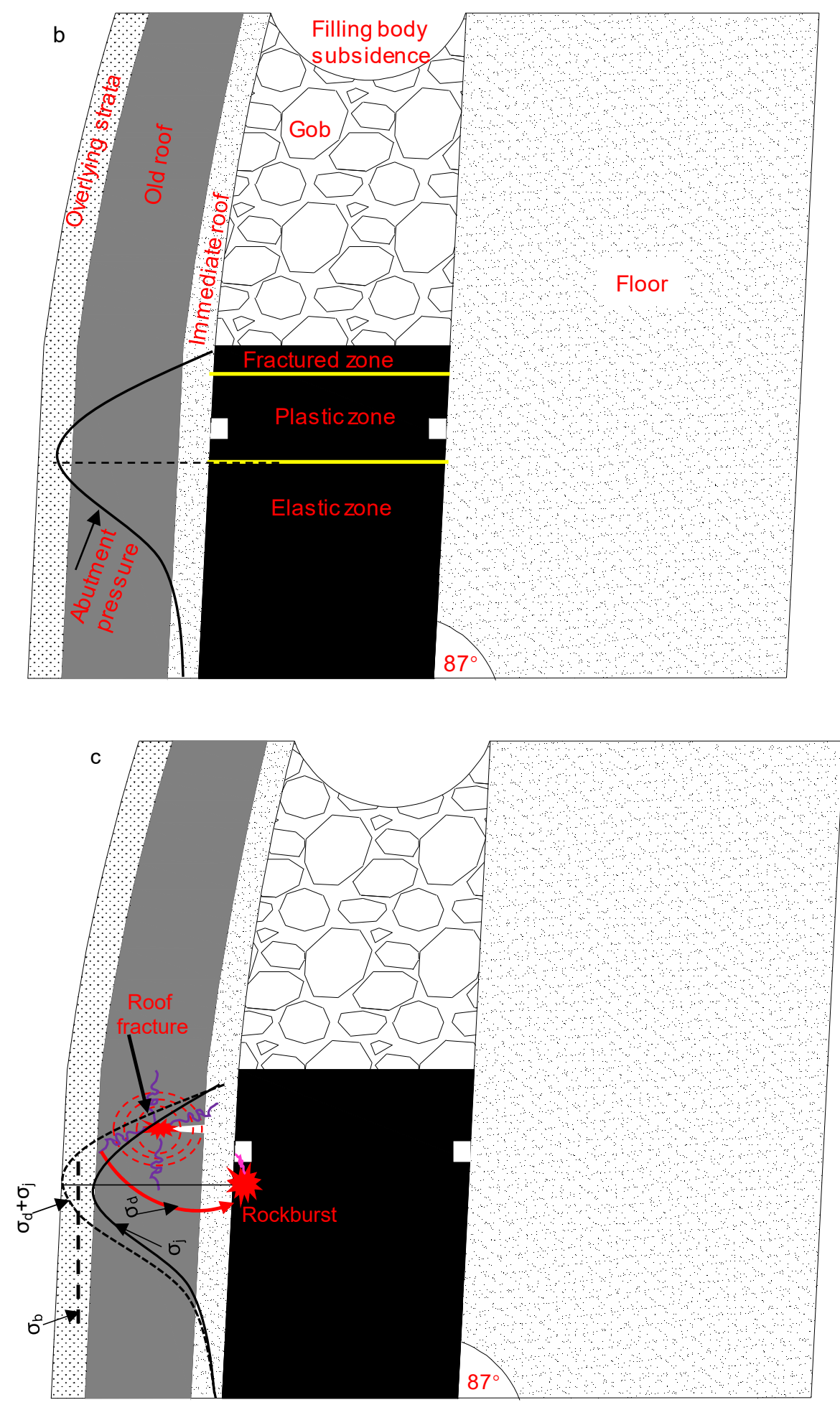

Figure 14. Mechanism of the rockburst in a steeply inclined and extremely thick coal seam (SIETCS): (a) the complete roof under filling conditions in the gob, (b) the roof bending and deformation caused by the subsidence of the gob filling and (c) the dynamic (induced by bending and breaking of the roof) and static combined loads inducing the rockburst.

\section{Controlling Measures and Effects}

The stress criterion for rockburst occurrence can be expressed in the form [17]

$$
\sigma_{j}+\sigma_{d}>\left[\sigma_{b}\right]
$$


where $\sigma_{j}$ is the static stress, $\sigma_{d}$ is the dynamic stress induced and $\left[\sigma_{b}\right]$ is the critical stress required for rockburst formation. The rockburst can be controlled by reducing $\sigma_{j}$ or $\sigma_{d}$, according to Equation (11).

The above research results show that the main factors that induced the rockburst of the SIETCS are the dynamic load stress generated by the bending and breaking of the roof and the static high-stress generated by the large horizontal stress and overburden applied to the coal through the roof. Destress blasting can loosen and crack the hard roof, destroy the integrity of the suspended roof, reduce the suspended length and static stress and partially release the energy accumulated in the hard roof [52-54]. Simultaneously, destroying the integrity of the roof can increase the attenuation of the shock wave velocity and amplitude, reducing the transmission of large horizontal stresses and overburden loads, thus decreasing the lateral pressure coefficient [55]. However, unreasonable blasting hole designs not only increase the costs but also induce secondary disasters. When only deep hole-blasting is used to relieve pressure, it is restricted by the sealing conditions; the roof is easy to form the "plate" structure and becomes the carrier of the surrounding rock stress, thus becoming the hazard source of the rockbursts, as shown in Figure 15. When only shallow hole-blasting is used, the pressure relief effect is not obvious. Therefore, it is particularly important to choose a reasonable method of blasting pressure relief.

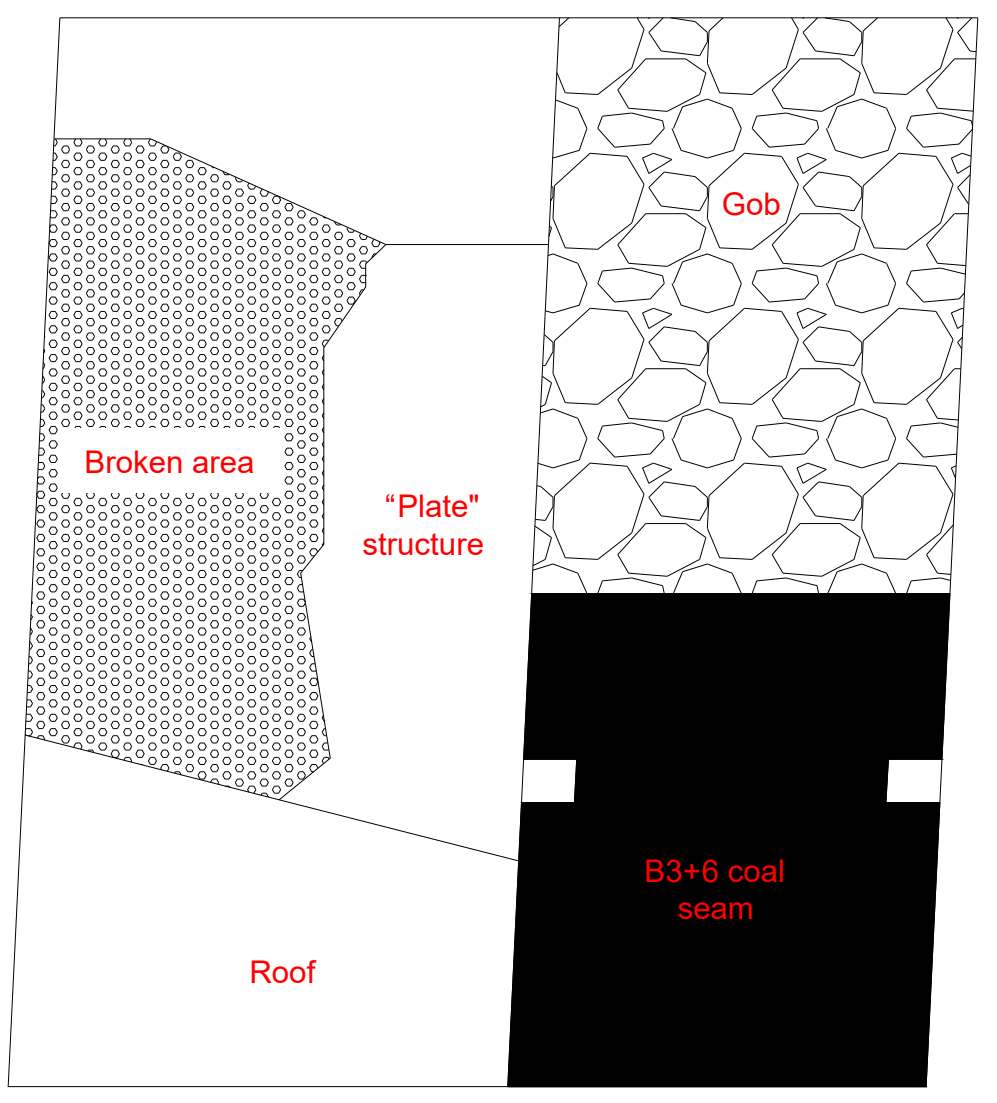

Figure 15. Schematic diagram of the "plate" structure produced by deep hole-blasting.

\subsection{Controlling Engineering}

Under the specific geological conditions of the WCM, according to the research results in Section 3, it is concluded that the EDE of the suspended roof under the gob filling condition obeys the following distribution function:

$$
U(x)=1.87 \times 10^{-6} x^{5.83}
$$

To make the energy stored in the roof less than the minimum energy $\left(1.3 \times 10^{5} \mathrm{~J}\right)$ required for roof failure, Formula (12) calculates that the suspended length of the roof should be less than $72.1 \mathrm{~m}$. 
Therefore, the breaking distance of the roof should be controlled at about $70 \mathrm{~m}$, so as to reduce the cost and ensure the pressure relief effect. Simultaneously, affected by geostress and other factors, the breaking distance decreases with the increase of the mining depth.

To select a better blasting pressure relief method to release the hard roof pressure, three sections with the same geological conditions and mining conditions are used to compare the pressure relief effects of three pressure relief projects (main pressure relief projects adopted in the WCM): i.e., deep hole-blasting companied with auxiliary shallow hole-blasting (A) - the row spacing of deep and shallow blasting holes are $10 \mathrm{~m}$ and $40 \mathrm{~m}$, respectively; alternate deep and shallow hole-blasting (B)-the row spacing of the deep and shallow blasting holes are $10 \mathrm{~m}$ and shallow hole-blasting accompanied with auxiliary deep hole-blasting (C) - the row spacing of deep and shallow blasting holes are $30 \mathrm{~m}$ and $10 \mathrm{~m}$, respectively. The three sections were 1485-1542 m, 1430-1485 m and1325-1430 m, respectively. These three methods were adopted for rockburst control in the No. B3 + 6 coal seam, as shown in Figure 16. All boreholes were arranged along the roadway of the floor and roof. The shallow holes are arranged with three holes per row. The deep holes are arranged with two holes in each row. The layout elevation of the deep and shallow blasting holes is shown in Figure 17. In Tables 4 and 5, borehole parameters for shallow and deep blasting holes were described, respectively.

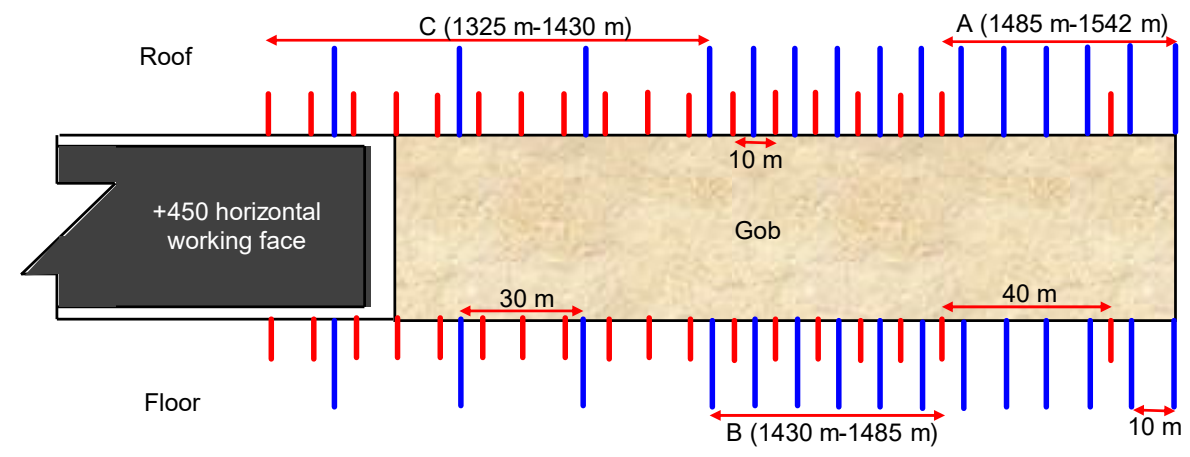

Figure 16. Layout plan of the blasting borehole.

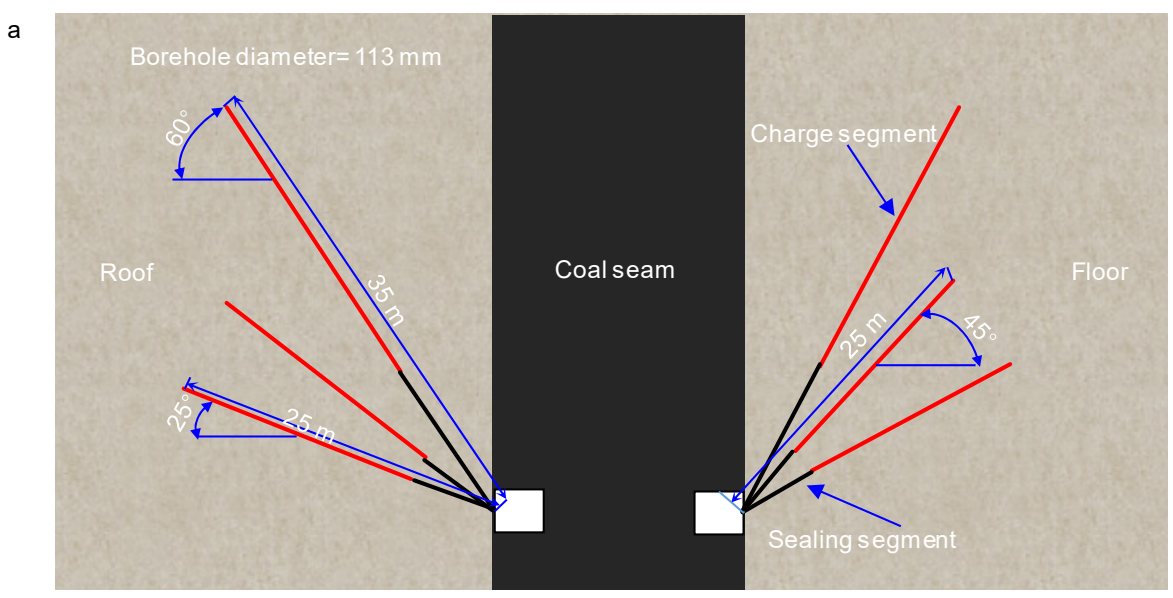

Figure 17. Cont. 


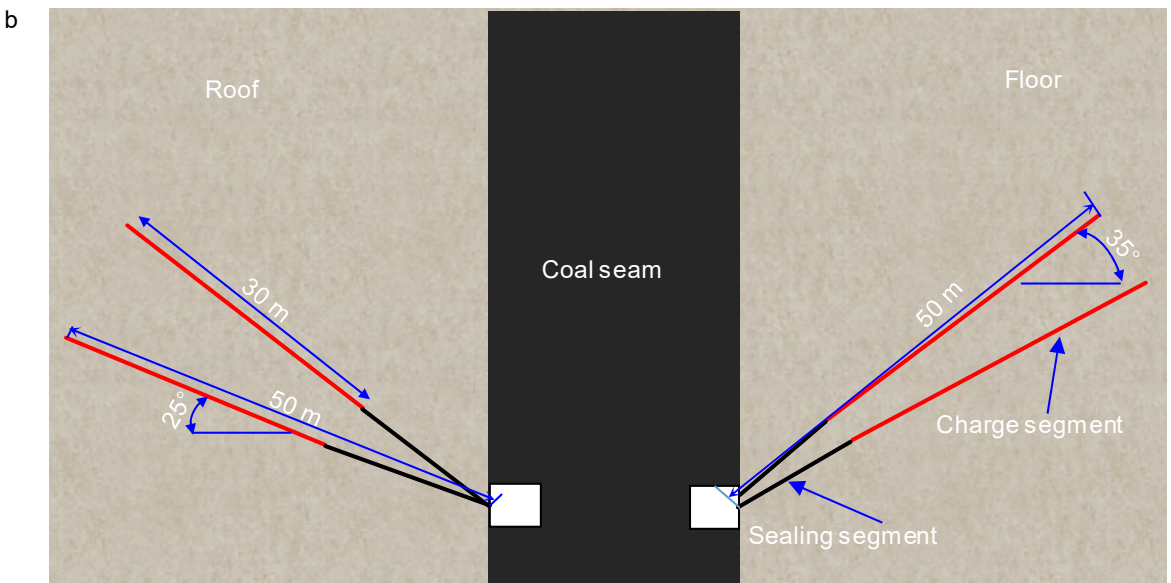

Figure 17. Layout elevation of blasting holes for a rock mass: (a) shallow blasting hole and (b) deep blasting hole.

Table 4. Borehole parameters for the shallow blasting hole.

\begin{tabular}{cccccc}
\hline$\#$ & $\begin{array}{c}\text { Borehole } \\
\text { Length }(\mathbf{m})\end{array}$ & $\begin{array}{c}\text { Borehole } \\
\text { Diameter }(\mathbf{m m})\end{array}$ & $\begin{array}{c}\text { Angle } \\
\left({ }^{\circ}\right)\end{array}$ & $\begin{array}{c}\text { Charge Segment } \\
\text { Length }(\mathbf{m})\end{array}$ & $\begin{array}{c}\text { Sealing Segment } \\
\text { Length }(\mathbf{m})\end{array}$ \\
\hline $1 \#$ & 25 & 0.113 & 25 & 15 & 10 \\
$2 \#$ & 25 & 0.113 & 45 & 15 & 10 \\
$3 \#$ & 35 & 0.113 & 60 & 23 & 12 \\
\hline
\end{tabular}

Table 5. Borehole parameters for the deep blasting hole.

\begin{tabular}{cccccc}
\hline$\#$ & $\begin{array}{c}\text { Borehole } \\
\text { Length }(\mathbf{m})\end{array}$ & $\begin{array}{c}\text { Borehole } \\
\text { Diameter }(\mathbf{m m})\end{array}$ & $\begin{array}{c}\text { Angle } \\
\left({ }^{\circ}\right)\end{array}$ & $\begin{array}{c}\text { Charge Segment } \\
\text { Length }(\mathbf{m})\end{array}$ & $\begin{array}{c}\text { Sealing Segment } \\
\text { Length }(\mathbf{m})\end{array}$ \\
\hline $1 \#$ & 50 & 0.113 & 25 & 20 & 30 \\
$2 \#$ & 50 & 0.113 & 35 & 20 & 30 \\
\hline
\end{tabular}

\subsection{Pressure Relief Effectiveness}

At present, the MS energy of a provoked tremor and event count are the main parameters to estimate the destress blasting effectiveness in coal mines [53,54]. The daily average energy and event count of the MS are $4.66 \times 10^{4} \mathrm{~J}$ and 33 , respectively, after the implementation of the B project. Compared with the effects of pressure relief with A and C, the daily monitoring energy decreases by $47.2 \%$ and $37.3 \%$, and the event count decreases by $38.7 \%$ and $11.8 \%$, respectively, as shown in Figure 18. The MS energy per meter decreased by $58.5 \%$ and $18.5 \%$, respectively, and the event count per meter decreased by $49.5 \%$ and $-3.5 \%$, as shown in Figure $18 \mathrm{~b}$.

The results show that the pressure relief effect of $B$ is more suitable for rockburst prevention and pressure relief in SIETCS. The main reason is that $B$ can enlarge the internal pressure relief range of the rock mass and destroy the "plate" structure formed by deep hole-blasting, which makes the hard roof break more effectively and increases the attenuation of the stress transfer process. 


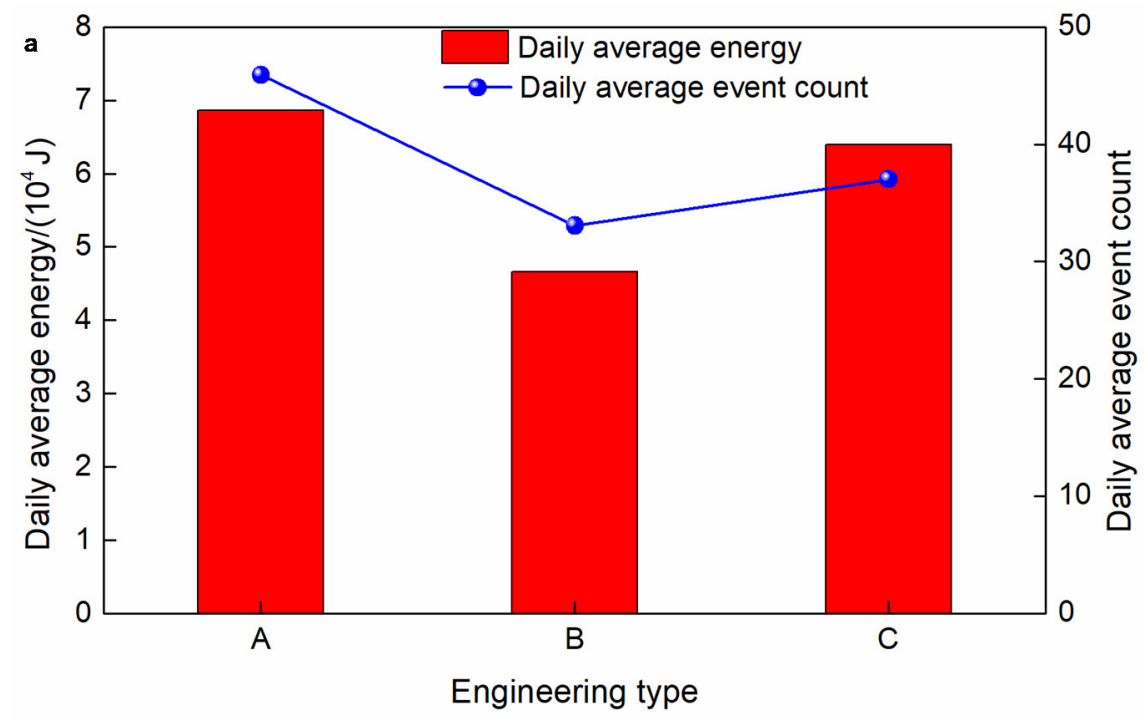

(a)

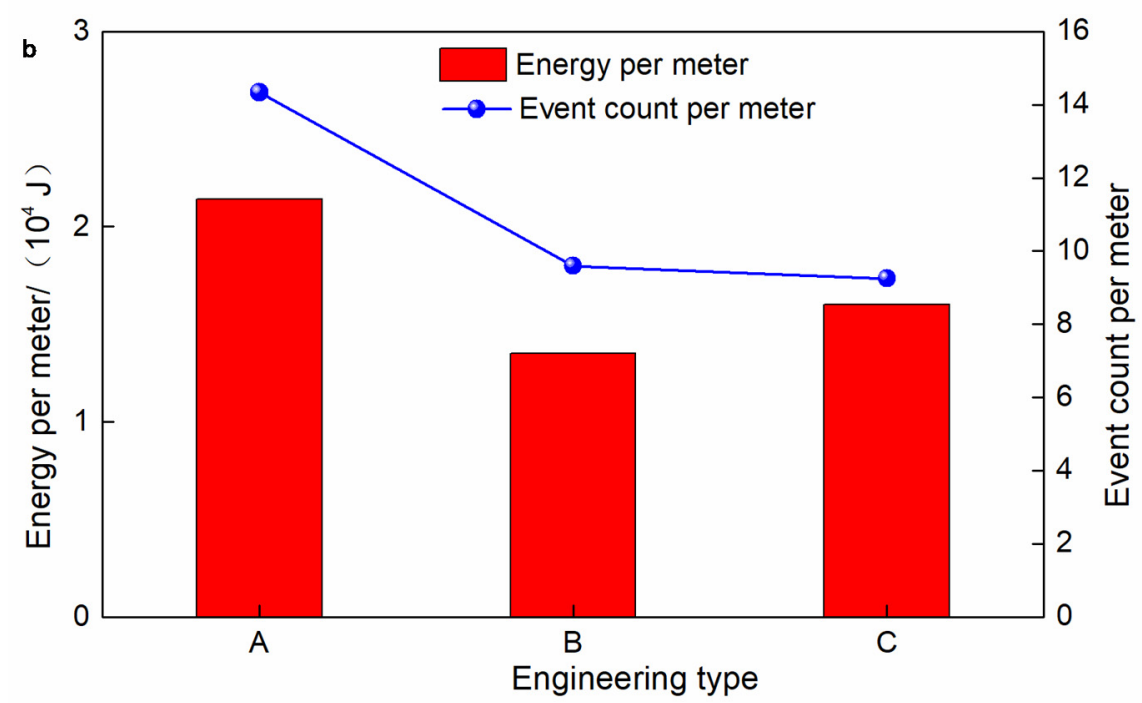

(b)

Figure 18. Pressure relief effectiveness of different pressure relief projects: (a) the daily average energy and event count and (b) the average energy per meter and event count per meter.

\section{Conclusions}

Taking the +450 horizontal of the No. B3 +6 coal seam in the WCM as an example, the rockburst mechanism of the SIETCS was studied. A mechanical model of a "steeply inclined suspended roof structure" was established, and the distribution of the EDE on the roof and the main influencing factors were studied. Simultaneously, the rockburst prevention and control measures of the SIETCS were optimized by comparing the pressure relief effects of different pressure relief projects. The central findings are listed below:

(1) The damage characteristics of the rockburst in the SIETCS shows an obvious directionality from roof side to coal side. The unstable bending and breaking of the steeply inclined suspended roof are the main factors for these directional damage characteristics.

(2) The mechanical model and the EDE distribution function of a "steeply inclined suspended roof structure" was developed. The EDE increases with an increasing dip angle of the coal seam 
between $0^{\circ}$ to $72.6^{\circ}$ and then decreases as the dip angle continually increases. Furthermore, the EDE increases as the lateral pressure coefficient and the supporting force coefficient decrease and is proportional to the inclination length of the suspended roof.

(3) Through theoretical analysis, the ground destruction measurement, MS monitoring and numerical simulation, the stress concentration areas of the coal and rock mass are obtained. The main rockburst triggering factor in the SIETCS of the WCM is the dynamic stress caused by the breakage of the suspended roof and the high static stress in the compressive area. The mechanisms of the rockburst on fully mechanized top-coal caving mining under gob filling conditions in an SIETCS are presented in this paper, i.e., "high compressive stress concentration plus breakage of the suspended roof induced stress" rockbursts.

(4) The safe and reasonable breaking span of the suspended roof has been obtained. The alternate deep and shallow hole-blasting mode is more suitable for rockburst prevention and pressure relief in an SIETCS by comparing three kinds of pressure relief projects: i.e., deep hole-blasting companied with auxiliary shallow hole-blasting, alternate deep and shallow hole-blasting and shallow hole-blasting accompanied with auxiliary deep hole-blasting.

Finally, the research cases in this paper are limited, and the rockburst mechanisms of SIETCS needs further research.

Author Contributions: Conceptualization, S.H. and D.S.; methodology, Z.L. and S.H.; validation, X.H. and Q.L.; investigation, Z.L. and T.Z.; data curation, J.C.; writing —original draft preparation, S.H. and Z.L.; writing-review and editing, D.S., Z.L. and J.C.; visualization, T.Z. and Q.L. and supervision, D.S. and X.H. All authors have read and agreed to the published version of the manuscript.

Funding: This work was supported, and financed, by the State Key Research Development Programme of China (No. 2016YFC0801408) and the National Natural Science Foundation of China (No. 51634001 and No. 51774023).

Acknowledgments: Special thanks should be extended to the Wudong Coal Mine for the provided raw data.

Conflicts of Interest: The authors confirm that there are no conflicts of interest associated with this publication.

\section{References}

1. Yan, H.; Zhang, J.X.; Feng, R.M.; Wang, W.; Lan, Y.W.; Xu, Z.J. Surrounding rock failure analysis of retreating roadways and the control technique for extra-thick coal seams under fully-mechanized top caving and intensive mining conditions: A case study. Tunn. Undergr. Space Technol. 2020, 97, 103241. [CrossRef]

2. Kaiser, P.K. Canadian Rockburst Support Handbook: 1996; Geomechanics Research Centre: Sudbury, ON, Canada, 1996.

3. Mazaira, A.; Konicek, P. Intense rockburst impacts in deep underground construction and their prevention. Can. Geotech. J. 2015, 52, 1426-1439. [CrossRef]

4. Chen, B.R.; Feng, X.T.; Li, Q.P.; Luo, R.Z.; Li, S.J. Rockburst intensity classification based on the radiated energy with damage intensity at jinping II hydropower station, China. Rock Mech. Rock Eng. 2015, 48, 289-303. [CrossRef]

5. Zhu, S.T.; Feng, Y.; Jiang, F.X. Determination of abutment pressure in coal mines with extremely thick alluvium stratum: A typical kind of rockburst mines in china. Rock Mech. Rock Eng. 2016, 49, 1943-1952. [CrossRef]

6. Cao, A.Y.; Dou, L.M.; Wang, C.B.; Yao, X.X.; Dong, J.Y.; Gu, Y. Microseismic precursory characteristics of rockburst hazard in mining areas near a large residual coal pillar: A case study from xuzhuang coal mine, xuzhou, China. Rock Mech. Rock Eng. 2016, 49, 4407-4422. [CrossRef]

7. Heib, M.A. Numerical and geophysical tools applied for the prediction of mine induced seismicity in French Coalmines. Int. J. Geosci. 2012, 3, 834-846. [CrossRef]

8. Zhu, S.T.; Feng, Y.; Jiang, F.X.; Liu, J.H. Mechanism and risk assessment of overall-instability-induced rockbursts in deep island longwall panels. Int. J. Rock Mech. Min. Sci. 2018, 106, 342-349. [CrossRef]

9. Cook, N.G.W. The seismic location of rockbursts. In Proceedings of the 5th Symposium on Rock Mechanics, Minneapolis, MN, USA, May 1962; pp. 493-516. 
10. Neyman, B.Z.; Szecowka, Z.; Zuberek, W. Effective methods for fighting rockbursts in polish collieries. In Proceedings of the 5th International Strata Control Conference, London, UK, 21 August 1972.

11. Singh, S.P. Burst energy release index. Rock Mech. Rock Eng. 1988, 21, 149-155. [CrossRef]

12. Dou, L.M.; Mu, Z.L.; Li, Z.L.; Cao, A.Y.; Gong, S.Y. Research progress of monitoring, forecasting, and prevention of rockburst in underground coal mining in China. Int. J. Coal Sci. Technol. 2014, 1, 278-288. [CrossRef]

13. Li, Z.L.; Dou, L.M.; Cai, W.; Wang, G.F.; He, J.; Gong, S.Y.; Ding, Y.L. Investigation and analysis of the rockburst mechanism induced within fault-pillars. Int. J. Rock Mech. Min. Sci. 2014, 70, 192-200. [CrossRef]

14. Guo, W.Y.; Zhao, T.B.; Tan, Y.L.; Yu, F.H.; Hu, S.C.; Yang, F.Q. Progressive mitigation method of rockbursts under complicated geological conditions. Int. J. Rock Mech. Min Sci. 2017, 96, 11-22. [CrossRef]

15. Lu, C.P.; Liu, G.J.; Liu, Y.; Zhang, H. Mechanisms of rockburst triggered by slip and fracture of coal-parting-coal structure discontinuities. Rock Mech. Rock Eng. 2019, 52, 3279-3292. [CrossRef]

16. Wang, G.F.; Gong, S.Y.; Dou, L.M.; Cai, W.; Yuan, X.Y.; Fan, C.J. Rockburst mechanism and control in coal seam with both syncline and hard strata. Saf. Sci. 2019, 115, 320-328. [CrossRef]

17. He, J.; Dou, L.M.; Cao, A.Y.; Gong, S.Y.; Lü, J.W. Rockburst induced by roof breakage and its prevention. J. Cent. South Univ. 2012, 19, 1086-1091. [CrossRef]

18. He, J.; Dou, L.M.; Gong, S.Y.; Li, J.; Ma, Z.Q. Rockburst assessment and prediction by dynamic and static stress analysis based on micro-seismic monitoring. Int. J. Rock Mech. Min Sci. 2017, 93, 46-53. [CrossRef]

19. Szwedzicki, T. Rock mass behaviour prior to failure. Int. J. Rock Mech. Min Sci. 2003, 40, 573-584. [CrossRef]

20. Wang, H.W.; Jiang, Y.D.; Xue, S.; Pang, X.F.; Lin, Z.N.; Deng, D.X. Investigation of intrinsic and external factors contributing to the occurrence of coal bumps in the mining area of Western Beijing, China. Rock Mech. Rock Eng. 2017, 50, 1033-1047. [CrossRef]

21. Cai, W.; Dou, L.M.; Si, G.Y.; Cao, A.Y.; He, J.; Liu, S. A principal componentanalysis/fuzzy comprehensive evaluation model for coal burst liability assessment. Int. J. Rock Mech. Min Sci. 2016, 81, 62-69. [CrossRef]

22. Islam, M.R.; Hayashi, D.; Kamruzzaman, A.B.M. Finite element modeling of stress distributions and problems for multi-slice long wall mining in Bangladesh, with special reference to the Barapukuria coal mine. Int. J. Coal Geol. 2009, 78, 91-109. [CrossRef]

23. Sirait, B.; Wattimena, R.K.; Widodo, N.P. Rockburst prediction of a cut and fill mine by using energy balance and induced stress. Procedia Earth Planet. Sci. 2013, 6, 426-434. [CrossRef]

24. Driad-Lebeau, L.; Lahaie, F.; Al Heib, A.; Josien, J.P.; Bigarre, P.; Noirel, J.F. Seismic and geotechnical investigations following a rockburst in a complex French mining district. Int. J. Coal Geol. 2005, 64, 66-78. [CrossRef]

25. Jiang, Y.D.; Wang, H.W.; Xue, S.; Zhao, Y.X.; Zhu, J.; Pang, X.F. Assessment and mitigation of coal bump risk during extraction of an island longwall panel. Int. J. Coal Geol. 2012, 95, 20-33. [CrossRef]

26. Wang, H.W.; Jiang, Y.D.; Zhao, Y.X.; Zhu, J.; Liu, S. Numerical investigation of the dynamic mechanical state of a coal pillar during longwall mining panel extraction. Rock Mech. Rock Eng. 2013, 46, 1211-1221. [CrossRef]

27. Marcak, H. Seismicity in mines due to roof layer bending. Arch. Min. Sci. 2012, 57, 229-250.

28. Lai, X.P.; Yang, Y.R.; Chen, J.Q. Control of dynamic hazards induced by mining stress distortion in extremely steep and thick coal seams. J. China Coal Soc. 2016, 41, 1610-1616.

29. Brauner, G. Rockbursts in Coal Mines and Their Prevention; Balkema, A.A., Ed.; CRC Press: Boca Raton, FL, USA, 1994.

30. Li, Z.L.; He, X.Q.; Dou, L.M.; Song, D.Z. Comparison of rockburst occurrence during extraction of thick coal seams using top-coal caving versus slicing mining methods. Can. Geotech. J. 2018, 55, 1433-1450. [CrossRef]

31. Singh, A.K.; Singh, R.; Maiti, J.; Kumar, R.; Mandal, P.K. Assessment of mining induced stress development over coal pillars during depillaring. Int. J. Rock Mech. Min Sci. 2011, 48, 794-804. [CrossRef]

32. Wang, G.F.; Gong, S.Y.; Dou, L.M.; Cai, W.; Jin, F.; Fan, C.J. Behaviour and bursting failure of roadways based on a pendulum impact test facility. Tunn. Undergr. Space Technol. 2019, 92, 103042. [CrossRef]

33. Huang, B.X.; Liu, J.W.; Zhang, Q. The reasonable breaking location of overhanging hard roof for directional hydraulic fracturing to control strong strata behaviors of gob-side entry. Int. J. Rock Mech. Min Sci. 2018, 103, 1-11. [CrossRef]

34. Fan, J.; Dou, L.M.; He, H.; Du, T.T.; Zhang, S.B.; Gui, B.; Sun, X.L. Directional hydraulic fracturing to control hard-roof rockburst in coal mines. Int. J. Min. Sci. Tech. 2012, 22, 177-181. [CrossRef] 
35. Feng, X.J.; Wang, E.Y.; Shen, R.X.; Wei, M.Y.; Chen, Y.; Cao, X.Q. The dynamic impact of rockburst induced by the fracture of the thick and hard key stratum. Procedia Eng. 2011, 26, 457-465.

36. Chen, G.X.; Dou, L.M.; Xu, X. Research on prevention of rockburst with relieving shot in roof. Procedia Eng. 2012, 45, 904-909. [CrossRef]

37. Lai, X.P.; Li, Y.P.; Wang, N.B.; Liu, Y.H.; Yan, P.J. Roof deformation characteristics with full-mechanized caving face based on beam structure in extremely inclined coal seam. J. Min. Saf. Eng. 2015, 32, 871-876.

38. Wang, Z.Y.; Dou, L.M.; Wang, G.F. Coal burst induced by horizontal section mining of a steeply inclined, extra-thick coal seam and its prevention: A case study from Yaojie No. 3 coal mine. China. Shock Vib. 2019, 2019, 8469019. [CrossRef]

39. He, S.Q.; Song, D.Z.; Li, Z.L.; He, X.Q.; Chen, J.Q.; Li, D.H.; Tian, X.H. Precursor of spatio-temporal evolution law of MS and AE activities for rockburst warning in steeply-inclined and extremely-thick coal seams under caving mining conditions. Rock Mech. Rock Eng. 2019, 52, 1-21. [CrossRef]

40. Hou, C.J.; Ma, N.J. Stress in in-seam roadway sides and limit equilibrium zone. J. China Coal Soc. 1989, 7, 21-29.

41. Lai, X.P.; Cai, M.F.; Ren, F.H.; Shan, P.F.; Cui, F.; Cao, J.T. Study on dynamic disaster in steeply deep rock mass condition in Urumchi Coalfield. Shock Vib. 2015, 2015, 465017. [CrossRef]

42. Zhao, Y.S.; Feng, Z.C.; Chang, Z.X. The least energy principle of dynamical rock failure. Chin. J. Rock Mech. Eng. 2002, 21, 1931-1933.

43. Zhang, H.W.; Rong, H.; Chen, J.Q.; Han, J.; Sun, B.C.; Huo, B.J.; Qi, T. Risk assessment of rockburst based on geo-dynamic division method in suberect and extremely thick coal seam. J. China Coal Soc. 2015, 40, 2755-2762.

44. Feng, G.L.; Feng, X.T.; Chen, B.R.; Xiao, Y.X.; Zhao, Z.N. Effects of structural planes on the microseismicity associated with rockburst development processes in deep tunnels of the Jinping-II Hydropower Station, China. Tunn. Undergr. Space Technol. 2019, 84, 273-280. [CrossRef]

45. Li, Z.L. Principle and Application of Rockburst Control by Weakening Static and Dynamic Loading Using Top-Coal Caving in the Mining of Thick Coal Seams. Ph.D. Thesis, China University of Mining and Technology, Xuzhou, China, 2016.

46. Pan, J.F.; Ning, Y.; Mao, D.B.; Lan, H.; Du, T.T.; Peng, Y.W. Theory of rockburst start-up during coal mining. Chin. J. Rock Mech. Eng. 2012, 31, 586-596.

47. Orlecka-Sikora, B. The role of static stress transfer in mining induced seismic events occurrence, a case study of the Rudna mine in the Legnica-Glogow Copper District in Poland. Geophys. J. Int. 2010, 182, 1087-1095. [CrossRef]

48. Ge, M. Efficient mine microseismic monitoring. Int. J. Coal Geol. 2005, 64, 44-56. [CrossRef]

49. Xu, N.W.; Tang, C.A.; Li, L.C.; Zhou, Z.; Sha, C.; Liang, Z.Z.; Yang, J.Y. Microseismic monitoring and stability analysis of the left bank slope in Jinping first stage hydropower station in southwestern China. Int. J. Rock Mech. Min Sci. 2011, 48, 950-963. [CrossRef]

50. Jiang, Q.A.; Feng, X.T.; Xiang, T.B.; Su, G.S. Rockburst characteristics and numerical simulation based on a new energy index: A case study of a tunnel at $2500 \mathrm{~m}$ depth. Bull. Eng. Geol. Environ. 2010, 69, 381-388. [CrossRef]

51. Labuz, J.F.; Zang, A. Mohr-coulomb failure criterion. In The ISRM Suggested Methods for Rock Characterization, Testing and Monitoring: 2007-2014; Springer: Berlin/Heidelberg, Germany, 2012; pp. 227-231.

52. Saharan, M.R.; Mitri, H. Destress blasting as a mines safety tool. Some fundamental challenges for successful applications. Procedia Eng. 2011, 26, 37-47. [CrossRef]

53. Konicek, P.; Soucek, K.; Stas, L.; Singh, R. Long-hole destress blasting for rockburst control during deep underground coal mining. Int. J. Rock Mech. Min. Sci. 2013, 61, 141-153. [CrossRef]

54. Wojtecki, Ł.; Konicek, P. Estimation of active rockburst prevention effectiveness during longwall mining under disadvantageous geological and mining conditions. J. Sustain. Min. 2016, 15, 1-7. [CrossRef]

55. Wojtecki, Ł.; Mendecki, M.J.; Zuberek, W.M. Determination of destress blasting effectiveness using seismic source parameters. Rock Mech. Rock Eng. 2017, 50, 3233-3244. [CrossRef]

(C) 2020 by the authors. Licensee MDPI, Basel, Switzerland. This article is an open access article distributed under the terms and conditions of the Creative Commons Attribution (CC BY) license (http://creativecommons.org/licenses/by/4.0/). 